\title{
NATIONAL BEEF QUALITY AUDIT-2011: IN-PLANT SURVEY OF \\ TARGETED CARCASS CHARACTERISTICS RELATED TO QUALITY, QUANTITY, VALUE, AND MARKETING OF FED STEERS AND HEIFERS
}

\author{
A Thesis \\ by \\ MELANIE CATHERINE MOORE \\ Submitted to the Office of Graduate Studies of \\ Texas A\&M University \\ in partial fulfillment of the requirements for the degree of \\ MASTER OF SCIENCE
}

Approved by:

Co-Chairs of Committee, Jeffrey W. Savell

Kerri B. Harris

Committee Member, Davey B. Griffin

Head of Department, H. Russell Cross

December 2012

Major Subject: Animal Science

Copyright 2012 Melanie Catherine Moore 


\begin{abstract}
The National Beef Quality Audit - 2011 assessed the current status of quality and consistency of fed steers and heifers. Beef carcasses $(n=9,802)$, representing approximately 10 percent of each production lot in 28 beef processing facilities, were selected randomly for the survey. Carcass evaluation for the cooler assessment of this study revealed these traits and frequencies: steer $(63.5 \%)$, heifer $(36.4 \%)$, cow $(0.1 \%)$, and bullock (0.03\%) sex classes; dark-cutters (3.2\%); blood splash (0.3\%); yellow fat $(0.1 \%)$; calloused ribeye $(0.05 \%)$; A $(92.8 \%), \mathrm{B}(6.0 \%)$, and $\mathrm{C}$ or greater $(1.2 \%)$ overall maturities; native (88.3\%), dairy-type (9.9\%), and Bos indicus (1.8\%) estimated breed types; and United States (97.7\%), Mexico (1.8\%), and Canada (0.5\%) country of origin. Certified or marketing program frequencies were age and source verified $(10.7 \%), \leq \mathrm{A}^{40}$ (10.0\%), Certified Angus Beef(9.3\%), top Choice (4.1\%), natural (0.6\%), and NonHormone Treated Cattle (0.5\%), and there were no organic programs observed. Mean USDA YG traits were USDA YG (2.9), HCW (374.0 kg), AFT (1.3 cm), LM area (88.8 $\mathrm{cm}^{2}$ ), and KPH (2.3\%); Frequencies of USDA YG distributions were YG 1 (12.4\%), YG $2(41.0 \%)$, YG $3(36.3 \%)$, YG $4(8.6 \%)$, and YG 5 (1.6\%). Mean USDA QG traits were USDA QG $\left(\right.$ Select $\left.^{93}\right)$, marbling score $\left(\right.$ Small $\left.^{40}\right)$, overall maturity $\left(A^{59}\right)$, lean maturity $\left(\mathrm{A}^{54}\right)$, skeletal maturity $\left(\mathrm{A}^{62}\right)$. Frequencies of USDA QG distributions were Prime (2.1\%), Choice (58.9\%), Select (32.6\%), and Standard or less (6.3\%). Marbling score distribution was Slightly Abundant or greater (2.3\%), Moderate (5.0\%), Modest (17.3\%), Small (39.7\%), Slight (34.6\%), and Traces or less (1.1\%). Carcasses with QG
\end{abstract}


of Select or greater and YG of 3 or numerically less represented $85.1 \%$ of the sample. This is the fifth benchmark study measuring targeted carcass characteristics, and information from this survey will continue to help drive progress in the beef industry. Results will be used in extension and educational programs as teaching tools to inform beef producers and industry professionals of the current state of the U.S. beef industry. 


\section{DEDICATION}

I dedicate this thesis and the work done for it to my family and friends. Without the love and constant support of my family, this could not have been achieved. They have been there for me through thick and thin and were always there when I needed

them most. To my friends, this work also could not have been completed without you. You all were the glue that held me together through graduate school, up to the completion of my thesis work, and even today. 


\section{ACKNOWLEDGEMENTS}

I thank my committee co-chairs, Dr. Jeffrey W. Savell and Dr. Kerri B. Harris

and committee member, Dr. Davey B. Griffin, for their guidance and support throughout the course of this research and my time here at Texas A\&M University, especially during these last two years of graduate school. Because of you all, I have been inspired to learn and study about an industry that intrigues me. You all have helped me in developing my abilities and myself as a well-rounded individual. Thank you for teaching me and sharing your wisdom and expertise in not only Meat Science and Food Safety but also life in general.

Many thanks also go to my friends and colleagues and the Meat Science Section faculty and staff for making my time at Texas A\&M University a great experience. Dr. Kerth, thank you very much for taking the time to help me with writing Excel formulas and equations used in analyzing my data. Also, thank you for your statistics expertise and unending guidance whenever I needed it. Dr. Hale, thank you for always being there and available if I ever had a question regarding anything or needed advice.

Words cannot begin to describe how thankful I am for my fellow graduate students. You have all been there for me on countless occasions and have always been more than willing to lend a helping hand no matter what. To Gatlan Gray and Leslie Frenzel, thank you both for traveling with me to do the majority of the cooler assessments at numerous different plants. I know traveling and being on the road for a research project can be stressful, but you both were very helpful. I could not have asked 
for better colleagues to travel with, and I know for a fact that the trips would not have been as fun as they were if the two of you were not there with me. To Kayla Nelson, Haley Grimes, Carson Ulbrich and Russell McKeith, thank you for your time and efforts in traveling and conducting cooler assessments as well. Without your help, this project would not have gone as smoothly as it did. To Meagan Igo, Cody Labus, Lindsey Mehall, Ashley Haneklaus, Amanda Smith, Jacob Lemmons, and to the rest of the graduate students, thank you all for any help that you have ever given me during my time here as a graduate student. Whether it included help with entering and checking data, covering my labs for me while I was traveling, taking notes for me in class, or just simply being there for me whenever I needed help and guidance, I greatly appreciate it all. Also, a big thank you to the Meat Science student workers, Julianne Riley, Jenny Bohac, Julie Lockhart, Rachel Glascock, and Jessica Stegar, who graciously made data books, mailed packages, and checked and entered data for countless hours. I would not have been able to complete this project in the time span I did if I did not have such a wonder team of professors, graduate students, colleagues, and student workers to graciously assist me.

I extend my gratitude to The Beef Checkoff for funding this project. Also, my sincere appreciation goes out to all the institutions that collaborated with Texas A\&M University and that served a part in this research. To the professors, graduate students, and industry leaders at The Pennsylvania University, Colorado State University, Oklahoma State University, West Texas A\&M University, California Polytechnic State University, USDA-ARS, and USDA-AMS, thank you all for taking part in this research. 
Thank you all for your time and effort put forth to complete this project. This work could not have been done without the collaboration of all these great institutions.

Finally, thanks to my parents for their encouragement and love. They have always pushed me to be the best I could and were one of the driving forces that lead me to complete my master's degree. They have always been there to celebrate my accomplishments during good times and to offer heartening words for when I was down during the bad. I would not be able to do the things I do if I did not have them backing me one hundred percent. Also, thank you to my sisters, Lacey and Sydney, for their continuous love and support. They were always there for me to lend a hand when I needed anything and to lend an ear for when I just needed someone to talk to. I would not have been able to accomplish anything without the love and support of my family. Thank you all for your undeniable inspiration and encouragement. 


\section{NOMENCLATURE}

AFT

AMS

CME

HCW

$\mathrm{KPH}$

LM

NBQA

NBQA-1991

NBQA-1995

NBQA-2000

NBQA-2005

NBQA-2011

QG

USDA

YG
Adjusted fat thickness

Agricultural Marketing Service

Chicago Mercantile Exchange

Hot carcass weight

Kidney, pelvic, and heart fat

Loin muscle

National Beef Quality Audit

National Beef Quality Audit - 1991

National Beef Quality Audit - 1995

National Beef Quality Audit - 2000

National Beef Quality Audit - 2005

National Beef Quality Audit - 2011

Quality grade

United States Department of Agriculture

Yield grade 


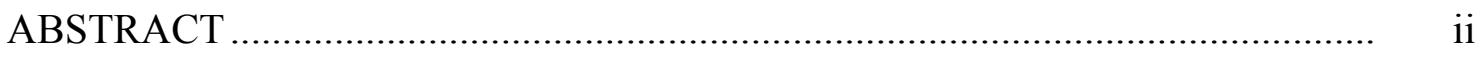

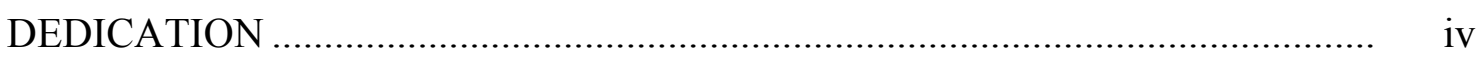

ACKNOWLEDGEMENTS ........................................................................

NOMENCLATURE ................................................................................. viii

TABLE OF CONTENTS .............................................................................. ix

LIST OF FIGURES .................................................................................. xi

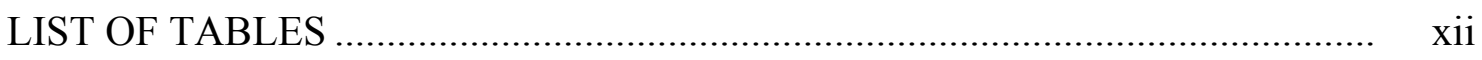

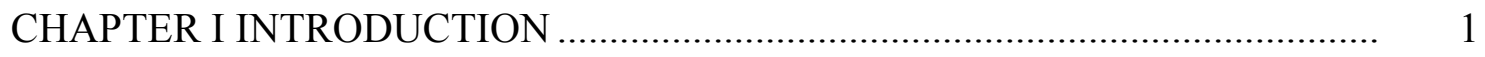

CHAPTER II REVIEW OF LITERATURE ........................................................

History of Beef Grading .................................................................................

Grades of Fed Beef Carcasses: November 1973-October 1974....................... 5

National Beef Quality Audit-1991 ............................................................... 6

National Beef Quality Audit-1995 ......................................................... 7

National Beef Quality Audit-2000 ................................................................ 8

National Beef Quality Audit-2005 ............................................................. 9

National Beef Quality Audit-2011 .............................................................. 9

CHAPTER III MATERIALS AND METHODS .................................................. 11

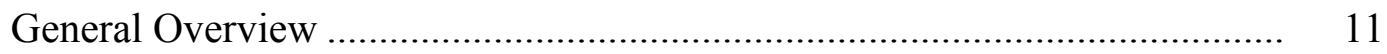

Carcass Assessment ………………………………................................ 11

Grade Determination ....................................................................... 12

Statistical Analysis .................................................................................. 13

CHAPTER IV RESULTS AND DISCUSSION ……………….......................... 14

CHAPTER V CONCLUSIONS ....................................................................... 22

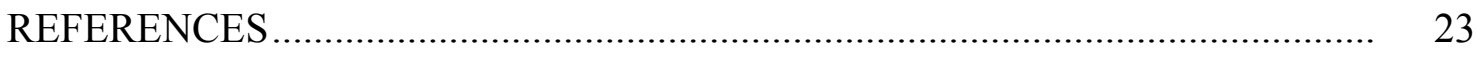




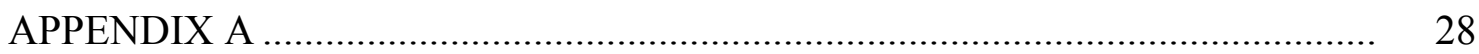

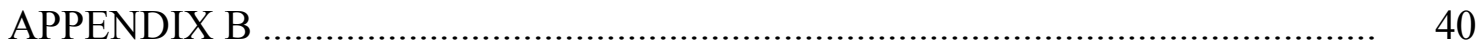




\section{LIST OF FIGURES}

Page

Figure 1 Example of data sheet used during data collection.....

Figure 2 Relationship between marbling, maturity, and carcass quality grade chart (USDA, 1997).

Figure 3 Frequency distribution of carcass by one-half yield grade increments.....

Figure 4 Frequency distribution of carcasses by weight groups..........................

Figure 5 Frequency distribution of different certified and marketing programs. ASV is age and source verified; A40 is for carcasses that meet the carcass maturity requirements for exporting to Japan; CAB is Certified Angus Beef; Top Choice is all other top Choice programs other than $\mathrm{CAB}$; Natural is for carcasses qualifying for natural programs; NHTC is Non-Hormone Treated Cattle; and Organic is for carcasses qualifying for organic programs 


\section{LIST OF TABLES}

Page

Table 1 Company and location of surveyed plants

Table 2 Means, standard deviations, and minimum and maximum values for USDA carcass grade traits

Table 3 Means for USDA carcass grade traits from NBQA-1991, NBQA-1995, NBQA-2000, NBQA-2005, and NBQA-2011

Table 4 Occurrence of marbling scores within USDA quality grades

Table 5 Percentage distribution of carcasses stratified by USDA quality and yield grades

Table 6 Characteristics of overall maturity

Table 7 Least squares means for carcass traits (SEM) within USDA quality grades

Table 8 Least squares means for carcass traits (SEM) within USDA yield grades

Table 9 Least squares means for carcass traits (SEM) within carcass weight groups.

Table 10 Least squares means for carcass traits (SEM) within fat thickness groups

Table 11 Least squares means for carcass traits (SEM) within sex class

Table 12 Least squares means for carcass traits (SEM) within estimated breed types 


\section{CHAPTER I}

\section{INTRODUCTION}

The NBQA began in the early 1990's and was the first benchmark study conducted to measure economically important characteristics of the U.S. fed beef supply since the USDA Market Consist Report (Abraham, 1977). Smith et al. (1992) suggested that audits be conducted every 4 to 5 years, so changes in the fed beef supply could be documented over time. Published results of the 4 previous audits include those of the NBQA-1991 (Lorenzen et al., 1993), NBQA-1995 (Boleman et al., 1998), NBQA-2000 (McKenna et al., 2002), and NBQA-2005 (Garcia et al., 2008). The NBQA provides valuable snapshots of the industry, and its quality challenges at specific points in time and findings are used to develop numerous producer-related extension workshops and industry research objectives.

The NBQA-2011 was conducted to assess the current status of consistency and quality of the U.S. fed beef population. This study also allowed measurement of the progress that has been made since the previous audit and identified needs for improvement. During the past twenty years, new policies and marketing practices, such as age and source verification, country of origin labeling (USDA, 2009), and development of certification programs, have impacted beef marketing. Fluctuations in the U.S economy, weather trends, improvement in cattle genetics, and varying cattle numbers could cause changes in the beef industry. For instance, the U.S. cattle population is currently at an all time low since 1973 totaling at 97.8 million head (CME 
Group, 2012). The NBQA-2011 was conducted to report the current quality and consistency of beef and identify issues that have developed since the last audit. Issues include those discussed at the NBQA-2011 Strategy Workshop such as inconsistent carcass weights, LM area, and fat thickness as well as the remaining existence of nonconforming carcasses (National Cattlemen's Beef Association, 2012). 


\section{CHAPTER II}

\section{REVIEW OF LITERATURE}

Over the years, the NBQA has been one of the most vital studies funded by The Beef Checkoff. Since 1991, these benchmark studies have been providing the beef industry with data identifying areas of non-conformity and quality shortfalls in products. There have been 4 studies in the United States which include the NBQA-1991 (Lorenzen et al., 1993), NBQA-1995 (Boleman et al., 1998), NBQA-2000 (McKenna et al., 2002), and NBQA-2005 (Garcia et al., 2008). Similar research studies were also conducted in

Canada. They include the Canadian Beef Quality Audit-1995-96 (Van Donkersgood et al., 1997) and the Canadian Beef Quality Audit-1998-99 (Van Donkersgood et al., 2001).

\section{History of Beef Grading}

Grades for dressed beef were seen in the beef industry as early as 1916 as tentative grades. The following year, in early 1917, grades were instated as a national service. Grades were established as a way to "sort" beef into similar groups making them more suitable for marketing. The first publication to consist of beef grades came out in August of 1924 and was the USDA Department Bulletin No. 1246 "Market Classes and Grades of Dressed Beef." Revised grade descriptions were then published in 1926 to provide the basis for beef grading when the voluntary grading and stamping service began in May 1927. 
Over the years, there have been many revisions made to the official standards through amendments with some of the most major changes being listed here. The first being in 1939 was to provide a single standard for grading steer, heifer, and cow beef according to similar quality characteristics. This amendment also changed grade terms for steer, heifer, and cow beef from "Medium" to "Commercial," "Common" to “Utility," and "Low Cutter" to "Canner." In November 1941, another amendment established grade terms for all beef to include the following grades: Prime, Choice, Good, Commercial, Utility, Cutter, and Canner. Later in October of 1949, all reference to fat color in quality grade determination was eliminated. In June 1965, official standards for grades of steer, heifer, and cow beef were changed to reflect less emphasis on maturity for in Prime, Choice, Good, and Standard grades. In July 1973, official standards were changed once again to provide a separate grading system for beef from young bulls or "bullocks." Quality grade standards for bullocks would essentially be the same as steer, heifer, and cow beef. However, there would only be five quality grades for the carcasses designated as bullocks. These grades were Prime, Choice, Good, Standard, and Utility. In November of 1987, official grade standards were revised to change the quality grade name U.S. Good to U.S. Select for steer, heifer, and cow beef. No grade requirements were change, just the grade name. Then in April 1989, an amendment changed grade standards to allow official grades of carcasses to include only quality grade, only yield grade, or a combination of both. The last amendment to the official grade standards occurred in 1997, and those changes still stand today as the United States Standards for Grades of Carcass Beef (USDA, 1997). 


\section{Grades of Fed Beef Carcasses: November 1973-October 1974}

Abraham et al. (1977) reported in the USDA Market Consist Report the distribution of quality and yield grades of the fed beef production. This report served as the first benchmark for determining changes in the US fed beef supply. Information found was used to assess the amount of beef in each grade. Knowledge of quality and yield grade consist and the factors that influence those grades was used to understand changes in beef productions and pinpoint areas of improvement. Data in this report also served as a database that future research could be compared to. Factors evaluated during this study were quality and yield grade factors, and they included the following: conformation, maturity, marbling, final quality grade, carcass weight, actual and adjusted fat over the ribeye, ribeye area, and estimated percentage kidney, pelvic, and heart fat, and final yield grade. The class of the carcass also was evaluated (steer, heifer, or bullock). Any other comments were also noted such as dark cutters, unusual conditions, or any other factors that would affect final quality grade.

Results from this study showed consist of quality and yield grades during at that point and time in the beef industry. Mean USDA YG was 3.4 with mean YG factors being the following: $\mathrm{HCW}$ was $307.9 \mathrm{~kg}$; fat thickness over ribeye, actual was $1.47 \mathrm{~cm}$; fat thickness over the ribeye, adjusted was $1.57 \mathrm{~cm}$; ribeye area was $75.7 \mathrm{~cm}^{2}$; estimated percentage kidney, pelvic, and heart fat was 3.0\%. Quality grade percentages were Prime (4.5\%), Choice (54.1\%), Good (39.9\%), and Standard (1.4\%). Yield grade percentages were YG 1 (4.1\%), YG 2 (25.7\%), YG 3 (43.9\%), YG 4 (20.5\%), and YG 5 $(5.8 \%)$. The frequency of dark cutters in this study was $1.4 \%$. 


\section{National Beef Quality Audit - 1991}

The first of the NBQAs began in 1991. The number one goal of the NBQA-1991 was "to conduct a quality audit of slaughter steers/heifers - their carcasses, cuts and dress-off/offal items - for the U.S. beef industry in 1991, establishing baselines for present quality shortfalls and identifying targets for desired quality levels by the year 2001" (National Cattlemen's Beef Association, 1992). The NBQA-1991 aimed to obtain quality and quantity attributes of beef during the cooler stage of the beef marketing sequence. This was done to serve as a benchmark for the beef industry to have to measure what was being produced. Results from this audit showed the following USDA YG means: USDA YG, 3.2; HCW, $345.0 \mathrm{~kg}$; AFT, $1.5 \mathrm{~cm}$; LM area, $83.4 \mathrm{~cm}^{2}$; and KPH percentage, 2.2 (Lorenzen et al., 1993). Mean USDA QG were the following: USDA QG, Select ${ }^{86}$; marbling score, Small ${ }^{24}$; lean maturity, $\mathrm{A}^{63}$; skeletal maturity, $\mathrm{A}^{75}$; and overall maturity, $\mathrm{A}^{69}$ (Lorenzen et al., 1993). When compared to the USDA Market Consist Report of 1974 (Abraham, 1977) the NBQA-1991 showed a numerical decrease $(P<0.05)$ of 0.3 in USDA YG, $0.08 \mathrm{~cm}$ less AFT, and $0.8 \%$ less KPH percentage as well as an increase in LM area of $7.1 \mathrm{~cm}^{2}$ and $\mathrm{HCW}$ increased by $36.8 \mathrm{~kg}$ (Lorenzen et al., 1993). This quality audit showed the beef feeding industry that cattle were being fed to heavier weights with approximately the same amount of subcutaneous fat and with less marbling with fewer high quality grades when compared to the USDA Market Consist Report (Abraham, 1977). The genetic change in cattle at that time lead to an increase in lean production and a reduction in total fat produced (Lorenzen et al., 1993). 


\section{National Beef Quality Audit - 1995}

Four years after the completion of the NBQA-1991, the second NBQA was conducted. The NBQA-1991 showed the beef industry that it was losing money through challenges it was facing, such as excess fat, lack of marbling, inconsistencies, and other carcass defects (Lorenzen et al., 1993). The NBQA-1995 aimed to assess whether or not progress had been made in correcting deficiencies and reducing quality concerns when comparing its results to those of the NBQA-1991 (National Cattlemen's Beef Association, 1995). The results from the NBQA-1995 showed a mixture of continued product deficiencies and successes in correcting those product quality shortfalls. Mean USDA YG and QG traits were the following: USDA YG, 2.8; HCW, $339.2 \mathrm{~kg}$; AFT, 1.2 cm; LM area, $82.6 \mathrm{~cm}^{2}$; KPH percentage, 2.1; USDA QG, Select ${ }^{79}$; marbling score, Small ${ }^{06}$; overall maturity, $\mathrm{A}^{60}$; skeletal maturity, $\mathrm{A}^{63}$; and lean maturity, $\mathrm{A}^{54}$ (Boleman et al., 1998). When compared with data from the NBQA-1991 (Lorenzen et al., 1993) carcasses in the NBQA-1995 were lower $(P<0.05)$ in USDA YG, AFT, HCW, KPH percentage, marbling score, and USDA QG. This quality audit proved the beef industry was moving in the right direction as far as producing a lean product. USDA YG 1 frequencies improved from $44 \%$ in 1991 to $58 \%$ in 1995 , and mean USDA YG improved from 3.16 in 1991 to 2.82 in 1995. Fat thickness also decreased from 1991 $(1.50 \mathrm{~cm})$ to $1995(1.19 \mathrm{~cm})$. However, percentage of Prime and Choice USDA QG carcasses decreased 7\% since the NBQA-1991 (Lorenzen et al., 1993). NBQA-1995 data indicate that overall, marbling scores have decreased. However, there were fewer carcasses with marbling scores that corresponded with USDA Standard (Boleman et al., 
1998). The NBQA-1995 provided cattle producers and the beef industry with information of the quality shortfalls of their product and provided them with some solutions for overcoming those problems (National Cattlemen's Beef Association, 1995).

\section{National Beef Quality Audit - 2000}

The NBQA-2000 was the third in a series of national audits that began in 1991. It continued to demonstrate the effort and progress the beef industry was making to improve the quality of its products. Mean USDA YG and QG traits were the following: USDA YG, 3.0; USDA QG, Select ${ }^{85}$; AFT, $1.2 \mathrm{~cm}$; HCW, $356.9 \mathrm{~kg}$; LM area, $84.5 \mathrm{~cm}^{2}$; KPH percentage, 2.4; marbling score, Small ${ }^{23}$; overall maturity, $\mathrm{A}^{66}$; skeletal maturity, $\mathrm{A}^{67}$; lean maturity, $\mathrm{A}^{65}$ (McKenna et al., 2002). The NBQA-2000 revealed a numerically greater mean YG of 3.0 when compared to the NBQA-1995. However, the AFT mean $(1.27 \mathrm{~cm})$ was numerically less than the mean found in the NBQA-1991 $(1.50 \mathrm{~cm})$. This audit also showed that HCW were increasing as well. In the NBQA2000, $\mathrm{HCW}$ averaged $354 \mathrm{~kg}$, which were $18 \mathrm{~kg}$ heavier than in 1995 and $12 \mathrm{~kg}$ heavier than in 1991. In addition, an increase in the percentage of Choice carcasses and a decrease in Select carcasses over the 1995 levels were noted (National Cattlemen's Beef Association, 2000). This audit suggested that producers had made measurable efforts in managing genetics for reduction of fat in beef products. 


\section{National Beef Quality Audit - 2005}

The NBQA-2005 was the fourth of previous and similar audits. Its intention, again, was to establish a new benchmark for shortfalls in beef cattle quality and identify new targets for the preferred quality of beef. In addition, this benchmark would be used as a tool in creating Beef Quality Assurance education efforts (National Cattlemen's Beef Association, 2005). Mean USDA YG and QG traits were the following: USDA YG, 2.9; USDA QG, Select ${ }^{90}$; AFT, $1.3 \mathrm{~cm}$; HCW, $359.9 \mathrm{~kg}$; LM area, $86.4 \mathrm{~cm}^{2}$; KPH

percentage, 2.3; marbling score, Small ${ }^{32}$; overall maturity, $\mathrm{A}^{64}$; skeletal maturity, $\mathrm{A}^{68}$; lean maturity, $\mathrm{A}^{57}$ (Garcia et al., 2008). This audit showed the continued increase in $\mathrm{HCW}$, which lead to one of the conclusions of the NBQA-2005 of focusing on target weights that optimize profitability without creating productivity or product desirability problems (National Cattlemen's Beef Association, 2005).

\section{National Beef Quality Audit - 2011}

The NBQAs do not provide the final word on beef quality through their extensive research efforts. They offer valuable snapshots of the beef industry along with its strengths and weaknesses at that given point in time. In order for the beef industry to be able to correct the areas it continues to struggle in, the NBQA must be conducted to determine exactly what those shortcomings are. Having the information the NBQAs contribute to the beef industry is key because it gives direction to producers, and the industry as a whole, as they search for methods to address and correct certain challenges. 
The NBQA-2011 will be the new benchmark for the beef industry, and it will help producers to improve the consistency and competitiveness of U.S. fed beef. 


\section{CHAPTER III}

\section{MATERIALS AND METHODS}

Institutional Animal Care and Use Committee approval was not obtained for this study because no live animals were involved.

\section{General Overview}

In-plant cooler audits were conducted in 28 federally inspected beef processing facilities throughout the United States selected to represent the major fed beef plants (Table 1). A correlation session was conducted with the collaborating institutions before the beginning of this study to ensure consistency of measurements and observations during data collection. These audits were conducted from May 2011 through February 2012 by personnel from 7 collaborating institutions. Beef processors were surveyed to obtain data representing the equivalent of one day's production, and both shifts were surveyed in those packing plants that process cattle during 2 shifts per day. Data were collected between Monday and Friday of a given week.

\section{Carcass Assessment}

Beef carcasses $(n=9,802)$, representing approximately 10 percent of each production lot, were selected randomly for the survey. Trained personnel evaluated beef carcasses to determine sex class (steer, heifer, cow or bullock), estimated breed type (native, dairy or Bos indicus), LM area (measured by either dot grid, blotting paper or 
video image analysis camera), HCW, carcass discounts (dark cutter, blood splash, calloused ribeye, yellow fat, etc.), certified or other marketing program, country of origin (USDA, 2009), and whether the carcass was from an animal 30 months of age or older. The sex class of surveyed carcasses was determined by USDA (1997) AMS standards. Estimated breed types were classified using the protocol established by Lorenzen et al. (1993): dairy type carcasses were those in which the conformation and overall muscling were angular and thin in relation to carcass size, Bos indicus type carcasses had dorsal thoracic humps (M. rhomboideus, overlying muscles, and subcutaneous fat) greater than $10.2 \mathrm{~cm}$, and carcasses with no readily distinguishable characteristics that would classify them as dairy or Bos indicus type were considered native. Carcasses qualifying for certified or other marketing programs were noted. United States Department of Agriculture, AMS, Meat Grading and Certification Branch personnel evaluated beef carcasses for lean maturity, skeletal maturity, marbling score, AFT, and KPH percentage (USDA, 1997).

\section{Grade Determination}

Factors collected using data sheets (Figure 1) during cooler assessment were entered and checked into Microsoft Excel for Mac 2011. A final quality grade was determined using quality grade factors that were evaluated and collected. Quality grades reported were based on the United States Standards for Grades of Carcass Beef (USDA, 1997). Maturity and marbling scores were combined using the Relationship Between Marbling, Maturity, and Carcass Quality Grade chart (USDA, 1997) depicted in Figure 2 
to determine quality grades. Yield grades reported were formulated from yield grade factors such as $\mathrm{AFT}, \mathrm{HCW}, \mathrm{LM}$ area, and $\mathrm{KPH}$ percentage. The equation used to determine yield grade is the same that is described in the official standards (USDA, 1997). The yield grade equation was the following: Yield grade $=2.50+(2.50 \times$ adjusted fat thickness, inches $)+(0.20 \times$ percent kidney, pelvic, and heart fat $)+(0.0038$ $\times$ hot carcass weight, pounds $)-(0.32 \times$ ribeye area, square inches $)$.

\section{Statistical Analysis}

All analyses were performed by using JMP Software (JMP Pro, Version 9.0.0, SAS Institute Inc., Cary, NC 1989-2010) and Microsoft Excel for Mac 2011. The Fit Y by $\mathrm{X}$ function was used for analysis of variance, and least squares means comparisons were performed using Student's t test. Frequency distributions, means, standard deviations, minimum, and maximum values were determined using the distribution function. Tables with $\mathrm{n}$ values that do not add up to $\mathrm{n}=9,802$ represent samples with missing data points. 


\section{CHAPTER IV}

\section{RESULTS AND DISCUSSION}

The mean USDA QG for the current study was Select ${ }^{93}$, whereas the mean USDA YG was 2.9 (Table 2). Means for USDA QG and YG (Table 3) were Select ${ }^{86}$ and 3.2 for NBQA-1991 (Lorenzen et al., 1993), Select $^{79}$ and 2.8 for NBQA-1995 (Boleman et al., 1998), Select ${ }^{85}$ and 3.0 for NBQA-2000 (McKenna et al., 2002), and Select $^{90}$ and 2.9 for NBQA-2005 (Garcia et al., 2008). Frequency distributions of carcasses by one-half yield grade increments are shown in Figure 3. The USDA YG distributions were YG 1 (12.4\%), YG 2 (41.0\%), YG 3 (36.3\%), YG 4 (8.6\%), and YG 5 (1.6\%). USDA YG distributions from NBQA-2005 (Garcia et al., 2008) were YG 1 (15.3\%), YG 2 (38.8\%), YG 3 (32.9\%), YG 4 (10.8\%), and YG 5 (2.2\%). The USDA QG distributions were Prime (2.1\%), Choice (58.9\%), Select (32.6\%), Standard (5.1\%), Commercial (0.9\%), and Utility (0.3\%). The USDA QG distributions from NBQA-2005 (Garcia et al., 2008) were Prime (2.6\%), Choice (51.9\%), Select (40.2\%), Standard (4.4\%), Commercial $(0.7 \%)$, and Utility $(0.3 \%)$. When data were compared from previous audits to the NBQA-2011 data, HCW and LM area both increased numerically, whereas AFT generally stayed constant. This indicates that cattle may be fed to a specific fat thickness endpoint even though carcass sizes and weights have increased. Since the last audit, $\beta$-adrenergic agonists that have become more widely used in the beef feeding industry (Delmore et al., 2010; Scramlin et al., 2010). An increase in HCW and LM area could also be from cattle genetics and management. One such example 
would be the use of Continental European breeds, which are known for being larger framed, leaner, and more muscular resulting in heavier HCW (Wheeler et al., 2005). Marbling scores across and within USDA QG are shown in Table 4. The majority of marbling scores are in the low parts of the grades (e.g., low Prime $=78.05 \%$, low Choice $=62.71 \%$, etc.). Occurrence of marbling score percentages within Moderate, Modest, and Small all increased numerically since NBQA-2005 (Garcia et al., 2008). McKenna et al. (2002) reported the need to determine the number of carcasses that were graded greater than or equal to $\mathrm{Small}^{50}$ because of the growing number of certified beef programs that include such carcasses. Current data shows that $41.2 \%$ of the carcasses surveyed had marbling scores greater than or equal to Small ${ }^{50}$, which was numerically greater than that reported (36.6\%) by McKenna et al. (2002) and (23.6\%) by Garcia et al. (2008). This increase could be related to the growing number of USDA Certified Beef Programs. Currently, there are 77 program or brand names among 44 companies that are certified by USDA. Thirty-nine of those programs have initial release dates after 2005 (USDA, 2012). Therefore, they were effective after the NBQA2005. Marbling score requirements of these programs vary, but the majority of the programs have a minimum of $\mathrm{Small}^{00}$. However, some also have minimum requirements of Small ${ }^{50}$. The number of marketing programs focusing on cattle that produce Choice or greater continues to increase and may be the cause of numerical increases in greater marbling scores in this audit. Table 4 also shows $46.7 \%$ of the Standard grade had Small marbling scores. This was due to carcasses having advanced 
maturities. Even though those carcasses had the marbling requirement to grade Choice, the overall maturity of those carcasses downgraded their quality grade to Standard.

Distributions of carcasses represented in the USDA QG by YG matrix are reported in Table 5. Carcasses that were Choice and Select, YG 2 and 3 comprised $72.0 \%$ of the sample; comparable percentages were $67.2 \%$ for NBQA-1991 (Lorenzen et al., 1993), 75.0\% for NBQA-1995 (Boleman et al., 1998), 70.5\% for NBQA-2000 (McKenna et al., 2002), and 67.2\% for NBQA-2005 (Garcia et al., 2008). Nonconforming carcasses-QG of Standard and lower and (or) YG 4 and 5represented $15.6 \%$ of the sample. Garcia et al. (2008) reported $18.3 \%$ of the carcasses in NBQA-2005 to be nonconforming.

Carcasses that were A-maturity comprised $92.8 \%$ of the carcasses sampled (Table 6). The Beef Export Verification program for Japan (USDA, 2005) requires that beef carcasses from cattle of unknown chronological ages must be $\mathrm{A}^{40}$ or more youthful in overall maturity. Of all carcasses evaluated, $23.2 \%$ were $\mathrm{A}^{40}$ or younger; within all A-maturity carcasses, $25.0 \%$ met this qualification. A numerical increase also was seen in the percentage of B maturity carcasses. The percentage of B maturity carcasses in NBQA-2011 was $6.0 \%$ as compared to $1.7 \%$ in the NBQA-2005.

In data not reported in tabular form, 3.2\% of the carcasses were dark cutters. The discounts for dark cutters were one-third grade (1.07\%), one-half grade (0.77\%), twothirds grade $(0.66 \%)$, and full grade $(0.69 \%)$. McKenna et al. (2002) reported $2.3 \%$ dark cutters with these discount distributions: one-third grade $(1.0 \%)$, one-half grade $(0.6 \%)$, two-thirds grade $(0.4 \%)$, and full grade $(0.3 \%)$. Data from the NBQA-2005 (Garcia et 
al., 2008) showed $1.9 \%$ of carcasses sampled were dark cutters with discounts of onethird grade $(0.7 \%)$, one-half grade $(0.3 \%)$, two-thirds grade $(0.3 \%)$, and full grade (0.5\%). Data from the NBQA-2011 showed an increase in percentage of dark cutters from previous audits: of those carcasses that qualified as dark cutters, $57.5 \%$ occurred during the fall and winter months of September through February. Other carcass defects included blood splash $(0.3 \%)$, yellow fat $(0.1 \%)$, and calloused ribeye $(0.05 \%)$.

Least squares means for carcass traits within each USDA QG are shown in Table 7. As QG increased from Standard to Prime, numerical YG, AFT, and KPH percentage increased $(P<0.05)$. This is to be expected because carcasses with higher quality grades tend to be fatter. Higher AFT and KPH percentage both cause YG to become numerically larger. In contrast, LM area decreased as QG increased from Standard to Prime. Carcasses that were Standard had greater $(P<0.05)$ marbling scores than those that graded Select. Those carcasses had marbling scores qualifying them for Choice or Prime quality grades. However, they were downgraded to the Standard grade because their overall maturity was B or older or they were discounted for being dark cutters. Carcasses qualifying for higher USDA QG had numerically larger HCW and smaller LM area, which is a trend that has been consistent throughout all the NBQAs.

Carcass trait means within each USDA YG are displayed in Table 8. As USDA YG increased (from YG 1 to YG 5), marbling, QG, AFT, HCW, and KPH percentage also increased, whereas LM area decreased $(P<0.05)$. This is to be expected because of how AFT, $\mathrm{HCW}, \mathrm{KPH}$, and LM area affect YG due to the USDA yield grade equation (USDA, 1997). Carcasses with greater yield grades are fatter and also tend to have 
greater marbling scores and QG. These relationships between carcass traits and USDA YG are similar to those reported by Lorenzen et al. (1993), Boleman et al. (1998), McKenna et al. (2002), and Garcia et al. (2008).

Carcass traits within HCW groups are displayed in Table 9. As HCW increased, numerical YG, AFT, marbling score, QG, and LM area increased $(P<0.05)$. These findings are comparable to those reported in the NBQA-2000 (McKenna et al., 2002) and the NBQA-2005 (Garcia et al., 2008). Frequency distribution of carcasses by weight group is reported in Figure 4. McKenna et al. (2002) discussed discounts for carcasses weighing $431 \mathrm{~kg}$ and reported $4.6 \%$ of carcasses in the NBQA-2000 exceeded this weight. Garcia et al. (2008) reported that 5.1\% of the carcasses in the NBQA-2005 weighted more than $431 \mathrm{~kg}$. Current data showed that $11.1 \%$ of the carcasses sampled exceed $431 \mathrm{~kg}$. However, in the beef industry today, it is more common to see major discounts for carcasses exceeding $454 \mathrm{~kg}$. In this study, 3.7\% of the carcasses sampled weighed greater than $454 \mathrm{~kg}$. HCW have gradually increased since the first NBQA1991 (Lorenzen et al., 1993). As previously mentioned, the prevalence of Continental European breeds in American breeding systems and the popularity in use of growth promotants and $\beta$-adrenergic agonists could have led to this increase in HCW. LM area numerically increased with each carcass weight group $(P<0.05)$. The trend of HWC and LM area increasing with each NBQA ties into one of the top priorities of reducing extremes in ribeye area and carcass weight discussed at the NBQA-2011 Strategy Workshop (National Cattlemen's Beef Association, 2012). 
Least squares means for carcass traits within fat thickness categories are reported in Table 10. As fat thickness increased, numerical YG, QG, HCW, and KPH percentage also increased $(P<0.05)$. The increase in marbling and $\mathrm{KPH}$ percentage as fat thickness increased was to be expected because the growth rates of these fat depots are related (Kempster, 1981). These relationships between carcass traits and USDA YG are similar to those reported by Lorenzen et al. (1993), Boleman et al. (1998), McKenna et al. (2002), and Garcia et al. (2008). Furthermore, Garcia et al. (2008) reported that QG increased $(P<0.05)$ with increasing fat thickness up to $1.51 \mathrm{~cm}$, but did not increase after that point. The same trend was seen in the data from the NBQA-2011. This shows that increasing fat thickness in cattle beyond a specific point does not ensure increased marbling or QG. In addition, the correlation coefficient between AFT and marbling was 0.3354, which shows that an increase in AFT does not necessarily mean that there will be an increase in marbling score.

The sex-class distribution of carcasses was: steers (63.47\%), heifers (36.37\%), cows $(0.13 \%)$, and bullocks $(0.03 \%)$. The percentages were similar to those reported in the NBQA-2005 (Garcia et al., 2008), which included steers (63.7\%), heifers (36.2\%), cows $(0.05 \%)$, and bullocks $(0.05 \%)$. Carcass traits stratified by sex class are displayed in Table 11. Carcasses from steers and heifers had more youthful $(P<0.05)$ overall maturity scores than carcasses from bullocks and cows. Bullock carcasses are younger than cows in chronological age and skeletal maturity. However, they tend to have more advanced lean maturities because bullock carcasses have ribeyes that are dark red in color and more coarse textured (USDA, 1997). Heifer carcasses had older overall 
maturity scores $\left(\mathrm{A}^{63}\right)$ than steer carcasses $\left(\mathrm{A}^{56}\right)$ in this study $(P<0.05)$. Steer carcasses had significantly $(P<0.05)$ heavier HCW and larger LM area than heifer carcasses. However, heifer carcasses had greater AFT, KPH, and marbling scores than steer carcasses. Bullock carcasses had $(P<0.05)$ smaller numerical YG, QG, and marbling scores than those of steer, heifer, and cow carcasses.

Current data showed that carcass estimated breed types were native type (88.3\%), dairy type (9.9\%), and Bos indicus $(1.8 \%)$. The trend for breed type seen over time in these surveys was an increasing number of carcasses classified as dairy type. Corresponding percentages of dairy carcasses from previous audits were $6.9 \%$ for NBQA-2000 (McKenna et al., 2002) and 8.3\% for NBQA-2005 (Garcia et al., 2008). Carcass traits stratified by estimated breed type are reported in Table 12. Among breed types, marbling score, HCW, KPH, and LM area differed significantly. Native-type carcasses had the greatest $(P<0.05)$ AFT, heaviest HCW, and the largest LM area. Dairy-type carcasses had greater $(P<0.05)$ marbling scores than the other two breed types.

The frequency distribution of carcasses from different countries of origin (USDA, 2009) were United States (97.7\%), Mexico (1.8\%), and Canada (0.5\%). Figure 5 displays the frequency distribution of carcasses identified as eligible for certain certified or marketing programs (USDA, 2012). Frequencies were as follows: age and source verified (10.7\%), $\leq \mathrm{A}^{40}(10.0 \%)$, Certified Angus Beef(9.3\%), top Choice (4.1\%), natural $(0.6 \%)$, and Non-Hormone Treated Cattle $(0.5 \%)$. There were no organic 
programs observed. This is the first time in the history of the National Beef Quality Audits that this information has been obtained. 


\section{CHAPTER V}

\section{CONCLUSIONS}

The NBQA serves as a benchmark study to measure and report certain producerrelated cattle and carcass traits in the US beef industry. Some of the trends observed in the NBQA-2011 included an increase in USDA Prime and Choice carcasses, increased HCW, increased LM area, and more dairy-type carcasses compared with previous audits. Also, the percentage of nonconforming carcasses - QG of Standard and lower and (or) YG 4 and 5-has decreased when compared to the last NBQA. This indicates that the beef industry is improving at providing a more uniform, consistent product. Information from this audit adds to the existing knowledge base of the beef industry regarding quality related attributes. Findings will be used to mark the progress that has been made in the industry and pinpoint the areas of improvement for the future. 


\section{REFERENCES}

Abraham, H. C. 1977. Grades of fed beef carcasses: November 1973-October 1974. Marketing Research Report Number 1073. United States Department of Agriculture, Agricultural Marketing Service, Washington, DC.

Boleman, S. L., S. J. Boleman, W. W. Morgan, D. S. Hale, D. B. Griffin, J. W. Savell, R. P. Ames, M. T. Smith, J. D. Tatum, T. G. Field, G. C. Smith, B. A. Gardner, J. B. Morgan, S. L. Northcutt, H. G. Dolezal, D. R. Gill, and F. K. Ray. 1998. National Beef Quality Audit-1995: Survey of producer-related defects and carcass quality and quantity attributes. J. Anim. Sci. 76: 96-103.

CME Group. 2012. Daily Livestock Report. CME Group, Inc., Chicago, IL. Accessed Aug. 1, 2012. http://www.dailylivestockreport.com/documents/dlr 07-232012.pdf.

Delmore, R. J., J. M. Hodgen, and B. J. Johnson. 2010. Perspectives on the application of zilpaterol hydrochloride in the United States beef industry. J. Anim. Sci. 88: 2825-2828.

Garcia, L. G., K. L. Nicholson, T. W. Hoffman, T. E. Lawrence, D. S. Hale, D. B. Griffin, J. W. Savell, D. L. VanOverbeke, J. B. Morgan, K. E. Belk, T. G. Field, J. A. Scanga, J. D. Tatum, and G. C. Smith. 2008. National Beef Quality Audit- 
2005: Survey of targeted cattle and carcass characteristics related to quality, quantity, and value of fed steers and heifers. J. Anim. Sci. 86: 3533-3543.

Kempster, A. J. 1981. Fat partition and distribution in the carcasses of cattle, sheep and pigs: A review. Meat Science 5: 83-98.

Lorenzen, C. L., D. S. Hale, D. B. Griffin, J. W. Savell, K. E. Belk, T. L. Frederick, M. F. Miller, T. H. Montgomery, and G. C. Smith. 1993. National Beef Quality Audit: Survey of producer-related defects and carcass quality and quantity attributes. J. Anim. Sci. 71: 1495-1502.

McKenna, D. R., D. L. Roeber, P. K. Bates, T. B. Schmidt, D. S. Hale, D. B. Griffin, J. W. Savell, J. C. Brooks, J. B. Morgan, T. H. Montgomery, K. E. Belk, and G. C. Smith. 2002. National Beef Quality Audit-2000: Survey of targeted cattle and carcass characteristics related to quality, quantity, and value of fed steers and heifers. J. Anim. Sci. 80: 1212-1222.

National Cattlemen's Beef Association. 1992. Executive Summary - National Beef Quality Audit. National Cattlemen's Beef Association, Englewood, CO.

National Cattlemen's Beef Association. 1995. The National Beef Quality Audit: Executive Summary, 1995 : Improving the Quality, Consistency, Competitiveness and Market-share of Beef : a Blueprint for Total Quality 
Management in the Beef Industry. National Cattlemen's Beef Association, Englewood, CO.

National Cattlemen's Beef Association. 2000. Executive Summary of the 2000 National Beef Quality Audit - Improving the quality, consistency, competitiveness and marketshare of beef. National Cattlemen's Beef Association, Centennial, CO. Accessed Aug. 1, 2012. http://beef.msu.edu/LinkClick.aspx?fileticket=aiqj\%2FeHudXo\%3D\&tabid=544.

National Cattlemen's Beef Association. 2005. Staying on Track - Executive Summary of the 2005 National Beef Quality Audit. National Cattlemen's Beef Association, Centennial, CO. Accessed Aug. 1, 2012. http://www.bqa.org/CMDocs/bqa/2005Audit.pdf.

National Cattlemen's Beef Association. 2012. Pillars of Beef Chain Success - Executive Summary: The 2011 National Beef Quality Audit. National Cattlemen's Beef Association, Centennial, CO. Accessed Aug. 1, 2012. http://www.bqa.org/CMDocs/bqa/NBQA.pdf.

Scramlin, S. M., W. J. Platter, R. A. Gomez, W. T. Choat, F. K. McKeith, and J. Killefer. 2010. Comparative effects of ractopamine hydrochloride and zilpaterol hydrochloride on growth performance, carcass traits, and longissimus tenderness of finishing steers. J. Anim. Sci. 88: 1823-1829. 
Smith, G. C., J. W. Savell, R. P. Clayton, T. G. Field, D. B. Griffin, D. S. Hale, M. F. Miller, T. H. Montgomery, J. B. Morgan, J. D. Tatum, and J. W. Wise. 1992. The Final Report of the National Beef Quality Audit-1991. p 236, National Cattlemen's Beef Association, Englewood, CO.

USDA. 1997. United States standards for grades of carcass beef. United States Department of Agriculture, Agricultural Marketing Service, Washington, DC. Accessed Mar. 26, 2012. http://www.ams.usda.gov/AMSv1.0/getfile?dDocName=STELDEV3002979.

USDA. 2005. USDA Export Verification (EV) Program Specified Product Requirements for Beef - Japan. Agricultural Marketing Service, United States Department of Agriculture, Washington, DC. Accessed May 15, 2012. http://www.ams.usda.gov/AMSv1.0/getfile?dDocName=STELDEV3103526.

USDA. 2012. USDA Certified Beef Programs. Agricultural Marketing Service, United States Department of Agriculture, Washington, DC. Accessed June 4, 2012. http://www.ams.usda.gov/AMSv1.0/getfile?dDocName=STELDEV3025674.

USDA, Agricultural Marketing Service. 2009. 7 CFR Parts 60 and 65: Mandatory Country of Origin Labeling of Beef, Pork, Lamb, Chicken, Goat Meat, Wild and Farm-Raised Fish and Shellfish, Perishable Agricultural Commodities, Peanuts, 
Pecans, Ginseng, and Macadamia Nuts; Final Rule. Accessed May 15, 2012. http://www.ams.usda.gov/AMSv1.0/getfile?dDocName=STELPRDC5074925.

Van Donkersgood, J., G. Jewison, S. Bygrove, K. Gillis, D. Malchow, and G. McLeod. 2001. Canadian beef quality audit 1998-99. Can. Vet. J. 42: 121-126.

Van Donkersgood, J., G. Jewison, M. Mann, B. Cherry, R. Altwaser, R. Lower, K. Wiggins, R. Dejonge, B. Thorlakson, E. Moss, C. Mills, and H. Grogan. 1997. Canadian beef quality audit. Can. Vet. J. 38: 217-225.

Wheeler, T. L., L. V. Cundiff, S. D. Shackelford, and M. Koohmaraie. 2005. Characterization of biological types of cattle (Cycle VII): Carcass, yield, and longissimus palatability traits. J. Anim. Sci. 83: 196-207. 


\section{APPENDIX A}

Table 1. Company and location of surveyed plants

\begin{tabular}{ll}
\hline \hline Company & Location \\
\hline AB Foods & Toppenish, WA \\
Cargill Meat Solutions & Fort Morgan, CO \\
Cargill Meat Solutions & Schuyler, NE \\
Cargill Meat Solutions & Dodge City, KS \\
Cargill Meat Solutions & Plainview, TX \\
Cargill Meat Solutions & Friona, TX \\
Creekstone Farms & Arkansas City, KS \\
Greater Omaha Packing Company & Omaha, NE \\
Harris Ranch Beef Company & Selma, CA \\
JBS Green Bay & Green Bay, WI \\
JBS Plainwell & Plainwell, MI \\
JBS Souderton & Souderton, PA \\
JBS Swift Cactus & Cactus, TX \\
JBS Swift Grand Island & Grand Island, NE \\
JBS Swift Greeley & Greeley, CO \\
JBS Swift Hyrum & Hyrum, UT \\
JBS Tolleson & Tolleson, AZ \\
National Beef & Brawley, CA \\
National Beef & Dodge City, KS \\
National Beef & Liberal, KS \\
Nebraska Beef & Omaha, NE \\
Sam Kane Beef Processors & Corpus Christi, TX \\
Tyson Fresh Meats & Joslin, IL \\
Tyson Fresh Meats & Finney County, KS \\
Tyson Fresh Meats & Dakota City, NE \\
Tyson Fresh Meats & Lexington, NE \\
Tyson Fresh Meats & Amarillo, TX \\
Tyson Fresh Meats & Pasco, WA \\
\hline
\end{tabular}


Table 2. Means, standard deviations, and minimum and maximum values for USDA carcass grade traits

\begin{tabular}{|c|c|c|c|c|}
\hline Trait & Mean & $\overline{\mathrm{SD}}$ & Minimum & Maximum \\
\hline USDA yield grade & 2.9 & 0.9 & -0.2 & 7.1 \\
\hline USDA quality grade $^{1}$ & 693 & 61 & 220 & 887 \\
\hline Adjusted fat thickness, $\mathrm{cm}$ & 1.30 & 0.52 & $-1.02^{4}$ & 3.96 \\
\hline $\mathrm{HCW}, \mathrm{kg}$ & 374.0 & 46.5 & 140.4 & 545.7 \\
\hline $\mathrm{LM}$ area, $\mathrm{cm}^{2}$ & 88.8 & 11.7 & 50.3 & 148.4 \\
\hline $\mathrm{KPH}, \%$ & 2.3 & 0.8 & 0.0 & 5.0 \\
\hline Marbling score ${ }^{2}$ & 440 & 98 & 100 & 960 \\
\hline Lean maturity $^{3}$ & 154 & 28 & 110 & 550 \\
\hline Skeletal maturity $^{3}$ & 162 & 34 & 100 & 600 \\
\hline Overall maturity $^{3}$ & 159 & 29 & 110 & 585 \\
\hline \multicolumn{5}{|c|}{$\begin{array}{l}{ }^{1} 100=\text { Canner }^{00}, 400=\text { Commercial }^{00}, 600=\text { Select }^{00}, \text { and }^{00}, 00=\text { Prime }^{00} \text {. } \\
{ }^{2} 100=\text { Practically devoid }^{00}, 300=\text { Slight }^{00}, 500=\text { Modest }^{00}, 700=\text { Slightly Abundant }^{00} \text {, } \\
\text { and } 900=\text { Abundant }^{00} \text {. } \\
{ }^{3} 100=\mathrm{A}^{00} \text { and } 500=\mathrm{E}^{00} \text {. } \\
{ }^{4} \text { Minimum value is less than } 0 \text { because of data conversion from a preliminary YG of less } \\
\text { than 2.0. }\end{array}$} \\
\hline
\end{tabular}


Table 3. Means for USDA carcass grade traits from NBQA-1991, NBQA-1995, NBQA2000, NBQA-2005, and NBQA-2011

\begin{tabular}{|c|c|c|c|c|c|}
\hline Trait & $\begin{array}{l}\text { NBQA- } \\
1991\end{array}$ & $\begin{array}{c}\text { NBQA- } \\
1995\end{array}$ & $\begin{array}{c}\text { NBQA- } \\
2000\end{array}$ & $\begin{array}{c}\text { NBQA- } \\
2005\end{array}$ & $\begin{array}{c}\text { NBQA- } \\
2011\end{array}$ \\
\hline USDA yield grade & 3.2 & 2.8 & 3.0 & 2.9 & 2.9 \\
\hline USDA quality grade $^{1}$ & 686 & 679 & 685 & 690 & 693 \\
\hline Adjusted fat thickness, $\mathrm{cm}$ & 1.5 & 1.2 & 1.2 & 1.3 & 1.3 \\
\hline $\mathrm{HCW}, \mathrm{kg}$ & 345.0 & 339.2 & 356.9 & 359.9 & 374.0 \\
\hline $\mathrm{LM}$ area, $\mathrm{cm}^{2}$ & 83.4 & 82.6 & 84.5 & 86.4 & 88.8 \\
\hline $\mathrm{KPH}, \%$ & 2.2 & 2.1 & 2.4 & 2.3 & 2.3 \\
\hline Marbling score ${ }^{2}$ & 424 & 406 & 423 & 432 & 440 \\
\hline Lean maturity $^{3}$ & 163 & 154 & 165 & 157 & 154 \\
\hline Skeletal maturity $^{3}$ & 175 & 163 & 167 & 168 & 162 \\
\hline Overall maturity $^{3}$ & 169 & 160 & 166 & 164 & 159 \\
\hline \multicolumn{6}{|c|}{$\begin{array}{l}{ }^{1} 100=\text { Canner }^{00}, 400=\text { Commercial }^{00}, 600=\text { Select }^{00}, \text { and }^{000}=\text { Prime }^{00} . \\
{ }^{2} 100=\text { Practically devoid }^{00}, 300=\text { Slight }^{00}, 500=\text { Modest }^{00}, 700=\text { Slightly Abundant }^{00} \text {, } \\
\text { and } 900=\text { Abundant } \\
{ }^{3} 100=\mathrm{A}^{00} \text { and } 500=\mathrm{E}^{00} .\end{array}$} \\
\hline
\end{tabular}


Table 4. Occurrence ${ }^{1}$ of marbling scores within USDA quality grades ${ }^{2}$

\begin{tabular}{lccccc}
\hline \hline Marbling score, $\%$ & Overall $^{3}$ & Prime & Choice & Select & Standard \\
\hline Abundant & 0.03 & 1.46 & & & \\
Moderately Abundant & 0.44 & 20.49 & & & \\
Slightly Abundant & 1.78 & 78.05 & 0.09 & & \\
Moderate & 4.99 & & 8.27 & & \\
Modest & 17.41 & & 28.93 & 0.06 & \\
Small & 39.89 & & 62.71 & 0.38 & 46.73 \\
Slight+ & 19.51 & & & 56.20 & 20.61 \\
Slight- & 14.85 & & & 43.35 & 11.63 \\
Traces & 1.02 & & & & 19.59 \\
Practically Devoid & 0.08 & & & & 1.43 \\
\hline
\end{tabular}

${ }^{1}$ Rounding error prevents all categories from adding to 100.0 .

${ }^{2}$ USDA quality grade was affected by maturity and dark cutting.

${ }^{3}$ Overall category represents USDA quality grades of Prime, Choice, Select, Standard, Commercial, Utility, and Cutter. 
Table 5. Percentage distribution ${ }^{1}$ of carcasses stratified by USDA quality ${ }^{2}$ and yield grades USDA USDA quality grade, $\%$

yield Prime Choice Select Standard Commercial Utility Cutter
grade

\begin{tabular}{cccccccc}
\hline 1 & 0.00 & 3.56 & 7.33 & 1.21 & 0.08 & 0.05 & 0.01 \\
2 & 0.37 & 22.77 & 15.34 & 2.02 & 0.26 & 0.14 & 0.01 \\
3 & 1.81 & 25.86 & 8.02 & 1.17 & 0.29 & 0.05 & 0.00 \\
4 & 0.53 & 6.32 & 1.37 & 0.26 & 0.14 & 0.04 & 0.00 \\
5 & 0.14 & 1.26 & 0.13 & 0.04 & 0.04 & 0.01 & 0.00 \\
\hline
\end{tabular}

${ }^{1}$ Carcasses with missing values for USDA quality or yield grades are not included.

${ }^{2}$ USDA quality grade was affected by maturity and dark-cutting beef, and there were no Canner carcasses observed in the audit. 
Table 6. Characteristics of overall maturity ${ }^{1}$

\begin{tabular}{crccccc}
\hline $\begin{array}{c}\text { Overall } \\
\text { maturity }\end{array}$ & $\mathrm{n}$ & $\begin{array}{c}\text { Percentage } \\
\text { of sample }\end{array}$ & Mean & SD & Minimum & Maximum \\
\hline A & 8,901 & 92.80 & 153 & 14 & 110 & 195 \\
B & 578 & 6.03 & 218 & 21 & 200 & 295 \\
C & 102 & 1.06 & 307 & 16 & 300 & 370 \\
D & 6 & 0.06 & 444 & 28 & 410 & 485 \\
E & 5 & 0.05 & 531 & 39 & 500 & 585 \\
\hline 1
\end{tabular}

${ }^{1} 100=\mathrm{A}^{00}, 200=\mathrm{B}^{00}, 300=\mathrm{C}^{00}, 400=\mathrm{D}^{00}$, and $500=\mathrm{E}^{00}$. 
Table 7. Least squares means for carcass traits $\left(\mathrm{SEM}^{1}\right)$ within USDA quality grades

\begin{tabular}{|c|c|c|c|c|}
\hline \multirow[b]{2}{*}{ Trait } & \multicolumn{4}{|c|}{ USDA quality grade } \\
\hline & $\begin{array}{c}\text { Prime } \\
(\mathrm{n}=205)\end{array}$ & $\begin{array}{c}\text { Choice } \\
(\mathrm{n}=5,634)\end{array}$ & $\begin{array}{c}\text { Select } \\
(\mathrm{n}=3,121)\end{array}$ & $\begin{array}{l}\text { Standard } \\
(\mathrm{n}=490)\end{array}$ \\
\hline USDA yield grade & $\begin{array}{l}3.7^{\mathrm{a}} \\
(006)\end{array}$ & $\begin{array}{l}3.1^{\mathrm{b}} \\
(001)\end{array}$ & $\begin{array}{l}2.6^{\mathrm{c}} \\
(002)\end{array}$ & $\begin{array}{l}2.6^{\mathrm{c}} \\
(0.04)\end{array}$ \\
\hline USDA quality grade $^{2}$ & $\begin{array}{l}819^{\mathrm{a}} \\
(1.59)\end{array}$ & $\begin{array}{c}727^{b} \\
(0.30)\end{array}$ & $\begin{array}{c}650^{\mathrm{c}} \\
(0.41)\end{array}$ & $\begin{array}{l}582^{\mathrm{d}} \\
(1.03)\end{array}$ \\
\hline Adjusted fat thickness, $\mathrm{cm}$ & $\begin{array}{r}1.68^{\mathrm{a}} \\
(0.03)\end{array}$ & $\begin{array}{l}1.40^{\mathrm{b}} \\
(0.008)\end{array}$ & $\begin{array}{l}1.14^{\mathrm{C}} \\
(0.009)\end{array}$ & $\begin{array}{l}1.11^{\mathrm{c}} \\
(0.02)\end{array}$ \\
\hline $\mathrm{HCW}, \mathrm{kg}$ & $\begin{array}{c}385.4^{\mathrm{a}} \\
(3.22)\end{array}$ & $\begin{array}{c}377.9^{\mathrm{b}} \\
(0.62)\end{array}$ & $\begin{array}{c}366.9^{\mathrm{d}} \\
(0.83)\end{array}$ & $\begin{array}{r}373.4^{\mathrm{c}} \\
(2.12)\end{array}$ \\
\hline $\mathrm{LM}$ area, $\mathrm{cm}^{2}$ & $\begin{array}{l}83.8^{\mathrm{c}} \\
(0.81)\end{array}$ & $\begin{array}{l}87.5^{\mathrm{b}} \\
(0.15)\end{array}$ & $\begin{array}{l}91.1^{\mathrm{a}} \\
(0.21)\end{array}$ & $\begin{array}{l}90.9^{\mathrm{a}} \\
(0.52)\end{array}$ \\
\hline $\mathrm{KPH}, \%$ & $\begin{array}{l}2.4^{\mathrm{a}} \\
(0.06)\end{array}$ & $\begin{array}{l}2.4^{\mathrm{a}} \\
(0.01)\end{array}$ & $\begin{array}{l}2.2^{\mathrm{b}} \\
(0.01)\end{array}$ & $\begin{array}{l}1.8^{\mathrm{c}} \\
(0.04)\end{array}$ \\
\hline Marbling score ${ }^{3}$ & $\begin{array}{l}759^{\mathrm{a}} \\
(4.0)\end{array}$ & $\begin{array}{c}484^{\mathrm{b}} \\
(0.8)\end{array}$ & $\begin{array}{l}351^{\mathrm{d}} \\
(1.0)\end{array}$ & $\begin{array}{c}377^{\mathrm{c}} \\
(2.6)\end{array}$ \\
\hline Lean maturity $^{4}$ & $\begin{array}{l}151^{\mathrm{b}} \\
(1.5)\end{array}$ & $\begin{array}{l}151^{\mathrm{b}} \\
(0.3)\end{array}$ & $\begin{array}{l}151^{\mathrm{b}} \\
(0.4)\end{array}$ & $\begin{array}{c}201^{\mathrm{a}} \\
(1.0)\end{array}$ \\
\hline Skeletal maturity $^{4}$ & $\begin{array}{l}160^{\mathrm{b}} \\
(1.6)\end{array}$ & $\begin{array}{l}159^{\mathrm{b}} \\
(0.3)\end{array}$ & $\begin{array}{l}154^{\mathrm{c}} \\
(0.4)\end{array}$ & $\begin{array}{r}206^{\mathrm{a}} \\
(1.0)\end{array}$ \\
\hline Overall maturity $^{4}$ & $\begin{array}{r}157^{\mathrm{b}} \\
(1.3)\end{array}$ & $\begin{array}{r}155^{\mathrm{b}} \\
(0.2)\end{array}$ & $\begin{array}{r}153^{\mathrm{c}} \\
(0.3)\end{array}$ & $\begin{array}{c}204^{\mathrm{a}} \\
(0.8)\end{array}$ \\
\hline
\end{tabular}


Table 8. Least squares means for carcass traits $\left(\mathrm{SEM}^{1}\right)$ within USDA yield grades

\begin{tabular}{|c|c|c|c|c|c|}
\hline \multirow[b]{2}{*}{ Trait } & \multicolumn{4}{|c|}{ USDA yield grade } & \multirow[b]{2}{*}{$\begin{array}{c}5 \\
(n=131)\end{array}$} \\
\hline & $\begin{array}{c}1 \\
(\mathrm{n}=1,012)\end{array}$ & $\begin{array}{c}2 \\
(\mathrm{n}=3,338)\end{array}$ & $\begin{array}{c}3 \\
(\mathrm{n}=2,955)\end{array}$ & $\begin{array}{c}4 \\
(\mathrm{n}=700)\end{array}$ & \\
\hline USDA yield grade & $\begin{array}{l}1.6^{\mathrm{e}} \\
(0.009)\end{array}$ & $\begin{array}{l}2.6^{\mathrm{d}} \\
(0.005)\end{array}$ & $\begin{array}{l}3.4^{\mathrm{c}} \\
(0.005)\end{array}$ & $\begin{array}{l}4.4^{\mathrm{b}} \\
(0.01)\end{array}$ & $\begin{array}{l}5.5^{\mathrm{a}} \\
(0.03)\end{array}$ \\
\hline USDA quality grade $^{2}$ & $\begin{array}{l}653^{\mathrm{e}} \\
(2.30)\end{array}$ & $\begin{array}{l}684^{\mathrm{d}} \\
(1.26)\end{array}$ & $\begin{array}{l}706^{\mathrm{c}} \\
(1.33)\end{array}$ & $\begin{array}{l}713^{\mathrm{b}} \\
(2.73)\end{array}$ & $\begin{array}{l}729^{\mathrm{a}} \\
(6.34)\end{array}$ \\
\hline Adjusted fat thickness, $\mathrm{cm}$ & $\begin{array}{c}0.72^{\mathrm{e}} \\
(0.01)\end{array}$ & $\begin{array}{l}1.08^{\mathrm{d}} \\
(0.006)\end{array}$ & $\begin{array}{l}1.45^{\mathrm{c}} \\
(0.006)\end{array}$ & $\begin{array}{l}2.05^{b} \\
(0.01)\end{array}$ & $\begin{array}{r}2.64^{\mathrm{a}} \\
(0.03)\end{array}$ \\
\hline $\mathrm{HCW}, \mathrm{kg}$ & $\begin{array}{c}351.8^{\mathrm{e}} \\
(1.36)\end{array}$ & $\begin{array}{r}368.7^{\mathrm{d}} \\
(0.75)\end{array}$ & $\begin{array}{c}383.3^{\mathrm{c}} \\
(0.80)\end{array}$ & $\begin{array}{c}399.8^{\mathrm{b}} \\
(1.64)\end{array}$ & $\begin{array}{r}411.1^{\mathrm{a}} \\
(3.79)\end{array}$ \\
\hline $\mathrm{LM}$ area, $\mathrm{cm}^{2}$ & $\begin{array}{c}100.3^{\mathrm{a}} \\
(0.32)\end{array}$ & $\begin{array}{l}91.4^{\mathrm{b}} \\
(0.17)\end{array}$ & $\begin{array}{l}84.8^{\mathrm{c}} \\
(0.18)\end{array}$ & $\begin{array}{l}81.1^{\mathrm{d}} \\
(0.38)\end{array}$ & $\begin{array}{l}75.2^{\mathrm{e}} \\
(0.88)\end{array}$ \\
\hline $\mathrm{KPH}, \%$ & $\begin{array}{l}1.96^{\mathrm{e}} \\
(0.02)\end{array}$ & $\begin{array}{r}2.19^{d} \\
(0.01)\end{array}$ & $\begin{array}{r}2.39^{c} \\
(0.01)\end{array}$ & $\begin{array}{r}2.62^{b} \\
(0.03)\end{array}$ & $\begin{array}{r}3.30^{\mathrm{a}} \\
(0.06)\end{array}$ \\
\hline Marbling score ${ }^{3}$ & $\begin{array}{c}373^{\mathrm{e}} \\
(2.9)\end{array}$ & $\begin{array}{c}422^{\mathrm{d}} \\
(1.6)\end{array}$ & $\begin{array}{c}466^{\mathrm{c}} \\
(1.7)\end{array}$ & $\begin{array}{c}497^{\mathrm{b}} \\
(3.4)\end{array}$ & $\begin{array}{l}543^{\mathrm{a}} \\
(7.9)\end{array}$ \\
\hline Lean maturity ${ }^{4}$ & $\begin{array}{l}157^{\mathrm{a}} \\
(0.9)\end{array}$ & $\begin{array}{l}155^{\mathrm{b}} \\
(0.5)\end{array}$ & $\begin{array}{l}152^{\mathrm{c}} \\
(0.5)\end{array}$ & $\begin{array}{r}153^{\mathrm{bc}} \\
(1.1)\end{array}$ & $\begin{array}{r}151^{\mathrm{bc}} \\
(2.5)\end{array}$ \\
\hline Skeletal maturity $^{4}$ & $\begin{array}{l}161^{\mathrm{b}} \\
(1.1)\end{array}$ & $\begin{array}{l}160^{\mathrm{b}} \\
(0.6)\end{array}$ & $\begin{array}{l}160^{\mathrm{b}} \\
(0.6)\end{array}$ & $\begin{array}{l}166^{\mathrm{a}} \\
(1.3)\end{array}$ & $\begin{array}{r}164^{\mathrm{ab}} \\
(2.9)\end{array}$ \\
\hline Overall maturity ${ }^{4}$ & $\begin{array}{l}159^{\mathrm{a}} \\
(0.9)\end{array}$ & $\begin{array}{r}158^{\mathrm{ab}} \\
(0.5)\end{array}$ & $\begin{array}{r}157^{\mathrm{b}} \\
(0.5)\end{array}$ & $\begin{array}{r}160^{\mathrm{a}} \\
(1.1)\end{array}$ & $\begin{array}{r}159^{\mathrm{ab}} \\
(2.1)\end{array}$ \\
\hline
\end{tabular}


Table 9. Least squares means for carcass traits $\left(\mathrm{SEM}^{1}\right)$ within carcass weight groups

\begin{tabular}{|c|c|c|c|c|c|c|c|}
\hline \multirow[b]{2}{*}{ Trait } & \multicolumn{7}{|c|}{ Carcass weight group, $\mathrm{kg}$} \\
\hline & $\begin{array}{c}<226.8 \\
(\mathrm{n}=14)\end{array}$ & $\begin{array}{c}226.8 \text { to } \\
272.1 \\
(n=136)\end{array}$ & $\begin{array}{c}272.2 \text { to } \\
317.5 \\
(n=933)\end{array}$ & $\begin{array}{c}317.5 \text { to } \\
362.8 \\
(\mathrm{n}=2,780)\end{array}$ & $\begin{array}{c}362.9 \text { to } \\
408.2 \\
(\mathrm{n}=3,524)\end{array}$ & $\begin{array}{c}408.2 \text { to } \\
453.5 \\
(\mathrm{n}=1,901)\end{array}$ & $\begin{array}{c}>453.5 \\
(n=359)\end{array}$ \\
\hline USDA yield grade & $\begin{array}{c}1.6^{\mathrm{g}} \\
(0.24)\end{array}$ & $\begin{array}{c}2.1^{\mathrm{f}} \\
(0.08)\end{array}$ & $\begin{array}{l}2.5^{\mathrm{e}} \\
(0.03)\end{array}$ & $\begin{array}{l}2.8^{\mathrm{d}} \\
(0.02)\end{array}$ & $\begin{array}{c}3.0^{\mathrm{c}} \\
(0.01)\end{array}$ & $\begin{array}{c}3.2^{b} \\
(0.02)\end{array}$ & $\begin{array}{c}3.6^{\mathrm{a}} \\
(0.05)\end{array}$ \\
\hline USDA quality grade $^{2}$ & $\begin{array}{l}621^{\mathrm{d}} \\
(19.85)\end{array}$ & $\begin{array}{l}654^{\mathrm{d}} \\
(6.44)\end{array}$ & $\begin{array}{l}680^{c} \\
(2.47)\end{array}$ & $\begin{array}{l}690^{\mathrm{b}} \\
(1.43)\end{array}$ & $\begin{array}{l}692^{\mathrm{b}} \\
(1.26)\end{array}$ & $\begin{array}{c}694^{\mathrm{ab}} \\
(1.72)\end{array}$ & $\begin{array}{l}702^{\mathrm{a}} \\
(3.93)\end{array}$ \\
\hline Adjusted fat thickness, $\mathrm{cm}$ & $\begin{array}{r}0.59^{f} \\
(0.13)\end{array}$ & $\begin{array}{r}0.85^{\mathrm{f}} \\
(0.04)\end{array}$ & $\begin{array}{l}1.09^{\mathrm{e}} \\
(0.02)\end{array}$ & $\begin{array}{l}1.23^{\mathrm{d}} \\
(0.01)\end{array}$ & $\begin{array}{c}1.33^{\mathrm{c}} \\
(0.008)\end{array}$ & $\begin{array}{r}1.40^{b} \\
(0.01)\end{array}$ & $\begin{array}{l}1.61^{\mathrm{a}} \\
(0.03)\end{array}$ \\
\hline $\mathrm{HCW}, \mathrm{kg}$ & $\begin{array}{r}197.4^{\mathrm{g}} \\
(3.44)\end{array}$ & $\begin{array}{r}257.1^{\mathrm{f}} \\
(1.10)\end{array}$ & $\begin{array}{c}300.6^{\mathrm{e}} \\
(0.42)\end{array}$ & $\begin{array}{c}342.6^{\mathrm{d}} \\
(0.24)\end{array}$ & $\begin{array}{c}384.9^{\mathrm{c}} \\
(0.22)\end{array}$ & $\begin{array}{r}426.9^{\mathrm{b}} \\
(0.30)\end{array}$ & $\begin{array}{c}472.0^{\mathrm{a}} \\
(0.68)\end{array}$ \\
\hline $\mathrm{LM}$ area, $\mathrm{cm}^{2}$ & $\begin{array}{l}68.2^{\mathrm{g}} \\
(2.84)\end{array}$ & $\begin{array}{l}74.4^{\mathrm{f}} \\
(0.91)\end{array}$ & $\begin{array}{l}80.4^{\mathrm{e}} \\
(0.35)\end{array}$ & $\begin{array}{l}85.3^{\mathrm{d}^{\prime}} \\
(0.20)\end{array}$ & $\begin{array}{l}90.1^{\mathrm{c}} \\
(0.18)\end{array}$ & $\begin{array}{l}94.5^{\mathrm{b}} \\
(0.24)\end{array}$ & $\begin{array}{l}97.8^{\mathrm{a}} \\
(0.56)\end{array}$ \\
\hline $\mathrm{KPH}, \%$ & $\begin{array}{l}1.8^{\mathrm{cd}} \\
(0.22)\end{array}$ & $\begin{array}{l}2.1^{\text {bcd }} \\
(0.08)\end{array}$ & $\begin{array}{c}2.3^{\mathrm{ab}} \\
(0.03)\end{array}$ & $\begin{array}{l}2.3^{\mathrm{a}} \\
(0.02)\end{array}$ & $\begin{array}{c}2.3^{\mathrm{a}} \\
(0.01)\end{array}$ & $\begin{array}{c}2.2^{\text {bc }} \\
(0.02)\end{array}$ & $\begin{array}{c}2.1^{\mathrm{d}^{\prime}} \\
(0.04)\end{array}$ \\
\hline Marbling score ${ }^{3}$ & $\begin{array}{l}360^{\mathrm{e}} \\
(25.9)\end{array}$ & $\begin{array}{l}378^{\mathrm{e}} \\
(8.3)\end{array}$ & $\begin{array}{c}416^{\mathrm{d}} \\
(3.2)\end{array}$ & $\begin{array}{c}433^{c} \\
(1.8)\end{array}$ & $\begin{array}{l}447^{\mathrm{b}} \\
(1.6)\end{array}$ & $\begin{array}{l}451^{\mathrm{b}} \\
(2.2)\end{array}$ & $\begin{array}{c}481^{\mathrm{a}} \\
(5.1)\end{array}$ \\
\hline Lean maturity $^{4}$ & $\begin{array}{l}191^{\mathrm{a}} \\
(7.2)\end{array}$ & $\begin{array}{r}158^{\mathrm{bc}} \\
(2.4)\end{array}$ & $\begin{array}{l}151^{\mathrm{d}} \\
(0.9)\end{array}$ & $\begin{array}{l}152^{\mathrm{d}} \\
(0.5)\end{array}$ & $\begin{array}{l}154^{\mathrm{c}} \\
(0.5)\end{array}$ & $\begin{array}{r}156^{\mathrm{bc}} \\
(0.6)\end{array}$ & $\begin{array}{c}158^{\mathrm{b}} \\
(1.4)\end{array}$ \\
\hline Skeletal maturity ${ }^{4}$ & $\begin{array}{c}185^{\mathrm{a}} \\
(9.0)\end{array}$ & $\begin{array}{r}158^{\mathrm{cd}} \\
(2.9)\end{array}$ & $\begin{array}{l}157^{\mathrm{d}} \\
(1.1)\end{array}$ & $\begin{array}{l}159^{\mathrm{d}} \\
(0.6)\end{array}$ & $\begin{array}{l}162^{\mathrm{c}} \\
(0.6)\end{array}$ & $\begin{array}{r}166^{\mathrm{b}} \\
(0.8)\end{array}$ & $\begin{array}{c}175^{\mathrm{a}} \\
(1.8)\end{array}$ \\
\hline Overall maturity $^{4}$ & $\begin{array}{r}188^{\mathrm{a}} \\
(7.5)\end{array}$ & $\begin{array}{r}158^{\text {cde }} \\
(2.4)\end{array}$ & $\begin{array}{l}154^{\mathrm{e}} \\
(0.9)\end{array}$ & $\begin{array}{c}156^{\mathrm{e}} \\
(0.5)\end{array}$ & $\begin{array}{r}159^{\mathrm{d}} \\
(0.5)\end{array}$ & $\begin{array}{c}162^{c} \\
(0.7)\end{array}$ & $\begin{array}{c}168^{\mathrm{b}} \\
(1.5)\end{array}$ \\
\hline
\end{tabular}

\footnotetext{
${ }^{\mathrm{a}-\mathrm{d}}$ Means within a row lacking a common superscript letter differ $(P<0.05)$

${ }^{1} \mathrm{SEM}$ is the SE of the least squares means.

${ }^{2} 100=$ Canner $^{00}, 400=$ Commercial $^{00}, 600=$ Select $^{00}$, and $800=$ Prime $^{00}$.

${ }^{3} 100=$ Practically devoid $^{00}, 300=$ Slight $^{00}, 500=$ Modest $^{00}$, and $700=$ Slightly Abundant $^{00}$.

${ }^{4} 100=\mathrm{A}^{00}$ and $500=\mathrm{E}^{00}$.
} 
Table 10. Least squares means for carcass traits $\left(\mathrm{SEM}^{1}\right)$ within fat thickness groups

\begin{tabular}{|c|c|c|c|c|c|c|c|c|c|c|}
\hline \multirow[b]{2}{*}{ Trait } & \multicolumn{10}{|c|}{ Fat thickness, cm } \\
\hline & $\begin{array}{c}<0.51 \\
(\mathrm{n}= \\
347)\end{array}$ & $\begin{array}{c}0.51 \text { to } \\
0.74 \\
(\mathrm{n}= \\
1,026)\end{array}$ & $\begin{array}{c}0.76 \text { to } \\
0.99 \\
(\mathrm{n}= \\
1,164)\end{array}$ & $\begin{array}{l}1.02 \text { to } \\
1.25 \\
(\mathrm{n}= \\
2,372)\end{array}$ & $\begin{array}{l}1.27 \text { to } \\
1.50 \\
(\mathrm{n}= \\
1,535)\end{array}$ & $\begin{array}{l}1.52 \text { to } \\
1.75 \\
(\mathrm{n}= \\
1,832)\end{array}$ & $\begin{array}{l}1.78 \text { to } \\
2.01 \\
(\mathrm{n}= \\
543)\end{array}$ & $\begin{array}{l}2.03 \text { to } \\
2.26 \\
(\mathrm{n}= \\
499)\end{array}$ & $\begin{array}{l}2.29 \text { to } \\
2.52 \\
(\mathrm{n}= \\
200)\end{array}$ & $\begin{array}{c}>2.52 \\
(\mathrm{n}= \\
208)\end{array}$ \\
\hline USDA yield grade & $\begin{array}{r}1.8^{j} \\
(0.03)\end{array}$ & $\begin{array}{r}2.1^{\mathrm{i}} \\
(0.02)\end{array}$ & $\begin{array}{r}2.4^{\mathrm{h}} \\
(0.02)\end{array}$ & $\begin{array}{r}2.7^{\mathrm{g}} \\
(0.01)\end{array}$ & $\begin{array}{r}3.0^{\mathrm{f}} \\
(0.02)\end{array}$ & $\begin{array}{r}3.4^{\mathrm{e}} \\
(0.01)\end{array}$ & $\begin{array}{r}3.7^{\mathrm{d}} \\
(0.03)\end{array}$ & $\begin{array}{r}4.1^{\mathrm{c}} \\
(0.03)\end{array}$ & $\begin{array}{r}4.3^{\mathrm{b}} \\
(0.04)\end{array}$ & $\begin{array}{r}5.0^{\mathrm{a}} \\
(0.04)\end{array}$ \\
\hline USDA quality grade ${ }^{2}$ & $\begin{array}{r}640^{\mathrm{g}} \\
(3.96)\end{array}$ & $\begin{array}{c}664^{\mathrm{f}} \\
(2.30)\end{array}$ & $\begin{array}{c}676^{\mathrm{e}} \\
(2.14)\end{array}$ & $\begin{array}{r}688^{\mathrm{d}} \\
(1.49)\end{array}$ & $\begin{array}{c}699^{c} \\
(1.85)\end{array}$ & $\begin{array}{c}702^{\mathrm{c}} \\
(1.69)\end{array}$ & $\begin{array}{c}710^{b} \\
(3.10)\end{array}$ & $\begin{array}{c}713^{\mathrm{ab}} \\
(3.24)\end{array}$ & $\begin{array}{c}706^{\mathrm{bc}} \\
(5.13)\end{array}$ & $\begin{array}{c}723^{\mathrm{a}} \\
(5.02)\end{array}$ \\
\hline $\begin{array}{l}\text { Adjusted fat thickness, } \\
\mathrm{cm}\end{array}$ & $\begin{array}{r}0.29^{\mathrm{j}} \\
(0.005)\end{array}$ & $\begin{array}{r}0.63^{\mathrm{i}} \\
(0.003\end{array}$ & $\begin{array}{r}0.87^{\mathrm{h}} \\
(0.003\end{array}$ & $\begin{array}{r}1.11^{\mathrm{g}} \\
(0.002\end{array}$ & $\begin{array}{r}1.37^{\mathrm{f}} \\
(0.002\end{array}$ & $\begin{array}{r}1.60^{\mathrm{e}} \\
(0.002\end{array}$ & $\begin{array}{r}1.86^{\mathrm{d}} \\
(0.004\end{array}$ & $\begin{array}{r}2.12^{\mathrm{c}} \\
(0.004\end{array}$ & $\begin{array}{r}2.38^{\mathrm{b}} \\
(0.006\end{array}$ & $\begin{array}{r}2.81^{\mathrm{a}} \\
(0.006)\end{array}$ \\
\hline $\mathrm{HCW}, \mathrm{kg}$ & $\begin{array}{c}341.2^{\mathrm{g}} \\
(2.25)\end{array}$ & $\begin{array}{c})^{\mathrm{f}} \\
355.7^{\mathrm{f}} \\
(1.42)\end{array}$ & $\begin{array}{c})^{\mathrm{e}} \\
365.7^{\mathrm{e}} \\
(1.33)\end{array}$ & $\begin{array}{c})^{\mathrm{d}} \\
373.0^{\mathrm{d}} \\
(0.93)\end{array}$ & $\begin{array}{c})^{\prime} \\
378.6^{\mathrm{c}} \\
(1.16)\end{array}$ & $\begin{array}{c})^{\mathrm{c}} \\
380.9^{\mathrm{c}} \\
(1.06)\end{array}$ & $\begin{array}{c})^{\mathrm{b}} \\
386.5^{\mathrm{b}} \\
(1.94)\end{array}$ & $\underset{\mathrm{b}}{)^{\mathrm{a}}}$ & $\underset{\mathrm{b}}{392.4^{\mathrm{a}}}$ & $\begin{array}{l}395.7^{\mathrm{a}} \\
(3.15)\end{array}$ \\
\hline $\mathrm{LM}$ area, $\mathrm{cm}^{2}$ & $\begin{array}{l}86.3^{\text {de }} \\
(0.62)\end{array}$ & $\begin{array}{c}89.1^{\mathrm{b}} \\
(0.36)\end{array}$ & $\begin{array}{c}90.6^{\mathrm{a}} \\
(0.34)\end{array}$ & $\begin{array}{c}89.6^{\mathrm{b}} \\
(0.24)\end{array}$ & $\begin{array}{c}89.6^{\mathrm{b}} \\
(0.30)\end{array}$ & $\begin{array}{c}88.1^{\mathrm{c}} \\
(0.27)\end{array}$ & $\begin{array}{l}87.2^{\mathrm{cd}} \\
(0.50)\end{array}$ & $\begin{array}{r}(2.03) \\
86.2^{\mathrm{d}} \\
(0.52)\end{array}$ & $\begin{array}{l}(3.18) \\
85.8^{\mathrm{de}} \\
(0.82)\end{array}$ & $\begin{array}{r}84.3^{\mathrm{e}} \\
(0.81)\end{array}$ \\
\hline $\mathrm{KPH}, \%$ & $\begin{array}{r}2.05^{\mathrm{f}} \\
(0.04)\end{array}$ & $\begin{array}{c}2.11^{\mathrm{f}} \\
(0.02)\end{array}$ & $\begin{array}{c}2.24^{\mathrm{e}} \\
(0.02)\end{array}$ & $\begin{array}{r}2.27^{\mathrm{e}} \\
(0.02)\end{array}$ & $\begin{array}{l}2.28^{\mathrm{de}} \\
(0.02)\end{array}$ & $\begin{array}{c}2.36^{\mathrm{c}} \\
(0.02)\end{array}$ & $\begin{array}{l}2.40^{b c} \\
(0.04)\end{array}$ & $\begin{array}{l}2.35^{\mathrm{cd}} \\
(0.04)\end{array}$ & $\begin{array}{c}2.51^{b} \\
(0.06)\end{array}$ & $\begin{array}{c}2.77^{\mathrm{a}} \\
(0.05)\end{array}$ \\
\hline Marbling score ${ }^{3}$ & $\begin{array}{l}369^{\mathrm{i}} \\
(5.0)\end{array}$ & $\begin{array}{l}394^{\mathrm{h}} \\
(2.9)\end{array}$ & $\begin{array}{l}409^{\mathrm{g}} \\
(2.7)\end{array}$ & $\begin{array}{l}432^{f} \\
(1.9)\end{array}$ & $\begin{array}{l}448^{\mathrm{e}} \\
(2.4)\end{array}$ & $\begin{array}{l}462^{\mathrm{d}} \\
(2.2)\end{array}$ & $\begin{array}{l}478^{c} \\
(4.0)\end{array}$ & $\begin{array}{l}495^{\mathrm{b}} \\
(4.1)\end{array}$ & $\begin{array}{l}501^{b} \\
(6.6)\end{array}$ & $\begin{array}{c}521^{\mathrm{a}} \\
(6.4)\end{array}$ \\
\hline Lean maturity ${ }^{4}$ & $\begin{array}{l}169^{\mathrm{a}} \\
(1.5)\end{array}$ & $\begin{array}{l}159^{b} \\
(0.9)\end{array}$ & $\begin{array}{l}154^{\mathrm{c}} \\
(0.8)\end{array}$ & $\begin{array}{l}154^{\mathrm{c}} \\
(0.6)\end{array}$ & $\begin{array}{l}153^{\mathrm{c}} \\
(0.7)\end{array}$ & $\begin{array}{l}153^{\mathrm{c}} \\
(0.7)\end{array}$ & $\begin{array}{l}152^{\mathrm{c}} \\
(1.2)\end{array}$ & $\begin{array}{l}154^{\mathrm{c}} \\
(1.2)\end{array}$ & $\begin{array}{l}154^{\mathrm{c}} \\
(2.0)\end{array}$ & $\begin{array}{c}151^{\mathrm{c}} \\
(1.9)\end{array}$ \\
\hline Skeletal maturity ${ }^{4}$ & $\begin{array}{r}164^{\mathrm{bcd}} \\
(1.8)\end{array}$ & $\begin{array}{l}160^{\mathrm{de}} \\
(1.1)\end{array}$ & $\begin{array}{l}158^{\mathrm{e}} \\
(1.0)\end{array}$ & $\begin{array}{l}159^{\mathrm{e}} \\
(0.7)\end{array}$ & $\begin{array}{r}162^{\mathrm{cd}} \\
(0.9)\end{array}$ & $\begin{array}{l}165^{\mathrm{b}} \\
(0.8)\end{array}$ & $\begin{array}{c}165^{\mathrm{bc}} \\
(1.5)\end{array}$ & $\begin{array}{l}173^{\mathrm{a}} \\
(1.5)\end{array}$ & $\begin{array}{c}169^{\mathrm{ab}} \\
(2.4)\end{array}$ & $\begin{array}{l}171^{\mathrm{a}} \\
(2.4)\end{array}$ \\
\hline Overall maturity ${ }^{4}$ & $\begin{array}{l}167^{\mathrm{a}} \\
(1.6)\end{array}$ & $\begin{array}{l}160^{\mathrm{bc}} \\
(0.9)\end{array}$ & $\begin{array}{l}156^{\mathrm{e}} \\
(0.9)\end{array}$ & $\begin{array}{l}157^{\mathrm{de}} \\
(0.6)\end{array}$ & $\begin{array}{r}158^{\text {cde }} \\
(0.7)\end{array}$ & $\begin{array}{r}160^{b c} \\
(0.7)\end{array}$ & $\begin{array}{r}159^{\mathrm{bcd}} \\
(1.2)\end{array}$ & $\begin{array}{l}165^{\mathrm{a}} \\
(1.3)\end{array}$ & $\begin{array}{l}162^{\mathrm{ab}} \\
(2.0)\end{array}$ & $\begin{array}{l}163^{\mathrm{ab}} \\
(2.0)\end{array}$ \\
\hline
\end{tabular}

\footnotetext{
${ }^{\mathrm{a}-\mathrm{d}}$ Means within a row lacking a common superscript letter differ $(P<0.05)$.

${ }^{1} \mathrm{SEM}$ is the SE of the least square means.

${ }^{2} 100=$ Canner $^{00}, 400=$ Commercial $^{00}, 600=$ Select $^{00}$, and $800=$ Prime $^{00}$.

${ }^{3} 100=$ Practically devoid $^{00}, 300=$ Slight $^{00}, 500=$ Modest $^{00}$, and $700=$ Slightly Abundant $^{00}$.

${ }^{4} 100=\mathrm{A}^{00}$ and $500=\mathrm{E}^{00}$.
} 
Table 11. Least squares means for carcass traits $\left(\mathrm{SEM}^{1}\right)$ within sex class

\begin{tabular}{|c|c|c|c|c|}
\hline \multirow[b]{2}{*}{ Trait } & \multicolumn{4}{|c|}{ Sex class } \\
\hline & $\begin{array}{c}\text { Steer } \\
(\mathrm{n}=6,171)\end{array}$ & $\begin{array}{c}\text { Heifer } \\
(\mathrm{n}=3,536)\end{array}$ & $\begin{array}{c}\text { Cow } \\
(\mathrm{n}=13)\end{array}$ & $\begin{array}{c}\text { Bullock } \\
(\mathrm{n}=3)\end{array}$ \\
\hline \multirow[t]{2}{*}{ USDA yield grade } & $3.0^{\mathrm{a}}$ & $2.9^{\mathrm{a}}$ & $2.6^{\mathrm{a}}$ & $1.4^{\mathrm{b}}$ \\
\hline & $(0.01)$ & $(0.02)$ & $(0.26)$ & $(0.50)$ \\
\hline \multirow[t]{2}{*}{ USDA quality grade $^{2}$} & $690^{\mathrm{a}}$ & $691^{\mathrm{a}}$ & $562^{\mathrm{b}}$ & $380.7^{\mathrm{c}}$ \\
\hline & $(0.97)$ & $(1.28)$ & $(20.97)$ & $(43.66)$ \\
\hline \multirow[t]{2}{*}{ Adjusted fat thickness, cm } & $1.23^{\mathrm{b}}$ & $1.41^{\mathrm{a}}$ & $0.73^{\mathrm{c}}$ & $0.51^{\mathrm{c}}$ \\
\hline & $(0.006)$ & $(0.009)$ & $(0.14)$ & $(0.29)$ \\
\hline \multirow[t]{2}{*}{$\mathrm{HCW}, \mathrm{kg}$} & $386.8^{\mathrm{a}}$ & $352.1^{\mathrm{b}}$ & $359.7^{\mathrm{b}}$ & $399.4^{\mathrm{ab}}$ \\
\hline & $(0.56)$ & $(0.73)$ & $(13.08)$ & $(25.05)$ \\
\hline \multirow[t]{2}{*}{$\mathrm{LM}$ area, $\mathrm{cm}^{2}$} & $89.2^{\mathrm{a}}$ & $88.0^{\mathrm{b}}$ & $77.9^{c}$ & $101.9^{\mathrm{a}}$ \\
\hline & $(0.15)$ & $(0.20)$ & $(3.24)$ & $(6.74)$ \\
\hline \multirow[t]{2}{*}{$\mathrm{KPH}, \%$} & $2.2^{\mathrm{b}}$ & $2.4^{\mathrm{a}}$ & $1.5^{\mathrm{c}}$ & $0.7^{\mathrm{c}}$ \\
\hline & $(0.01)$ & $(0.01)$ & $(0.21)$ & $(0.43)$ \\
\hline \multirow[t]{2}{*}{ Marbling score ${ }^{3}$} & $436^{\mathrm{b}}$ & $448^{\mathrm{a}}$ & $488^{\mathrm{ab}}$ & $280^{\mathrm{c}}$ \\
\hline & $(1.3)$ & $(1.7)$ & $(27.1)$ & $(56.5)$ \\
\hline \multirow{2}{*}{ Lean maturity $^{4}$} & $154^{\mathrm{d}}$ & $155^{\mathrm{c}}$ & $232^{\mathrm{b}}$ & $400^{\mathrm{a}}$ \\
\hline & $(0.4)$ & $(0.5)$ & $(7.6)$ & (19.3) \\
\hline \multirow[t]{2}{*}{ Skeletal maturity $^{4}$} & $158^{\mathrm{c}}$ & $169^{b}$ & $302^{\mathrm{a}}$ & $177^{\mathrm{bc}}$ \\
\hline & $(0.4)$ & $(0.6)$ & $(9.2)$ & (19.2) \\
\hline \multirow[t]{2}{*}{ Overall maturity ${ }^{4}$} & $156^{\mathrm{c}}$ & $163^{\mathrm{b}}$ & $276^{\mathrm{a}}$ & $275^{\mathrm{a}}$ \\
\hline & $(0.4)$ & $(0.5)$ & $(7.8)$ & $(19.8)$ \\
\hline
\end{tabular}


Table 12. Least squares means for carcass traits $\left(\mathrm{SEM}^{1}\right)$ within estimated breed types

\begin{tabular}{|c|c|c|c|}
\hline \multirow[b]{2}{*}{ Trait } & \multicolumn{3}{|c|}{ Estimated breed type } \\
\hline & $\begin{array}{c}\text { Native } \\
(\mathrm{n}=7,776)\end{array}$ & $\begin{array}{c}\text { Dairy } \\
(\mathrm{n}=876)\end{array}$ & $\begin{array}{c}\text { Bos indicus } \\
(\mathrm{n}=159)\end{array}$ \\
\hline \multirow[t]{2}{*}{ USDA yield grade } & $2.9^{\mathrm{a}}$ & $2.9^{\mathrm{a}}$ & $2.7^{b}$ \\
\hline & $(0.01)$ & $(0.03)$ & $(0.07)$ \\
\hline \multirow[t]{2}{*}{ USDA quality grade $^{2}$} & $689^{a}$ & $695^{\mathrm{a}}$ & $689^{\mathrm{a}}$ \\
\hline & $(0.88)$ & $(2.66)$ & $(6.13)$ \\
\hline \multirow[t]{2}{*}{ Adjusted fat thickness, $\mathrm{cm}$} & $1.34^{\mathrm{a}}$ & $0.80^{\mathrm{c}}$ & $0.99^{b}$ \\
\hline & $(0.005)$ & $(0.02)$ & $(0.04)$ \\
\hline \multirow[t]{2}{*}{$\mathrm{HCW}, \mathrm{kg}$} & $375.2^{\mathrm{a}}$ & $367.7^{\mathrm{b}}$ & $335.2^{\mathrm{c}}$ \\
\hline & $(0.53)$ & $(1.57)$ & $(3.77)$ \\
\hline \multirow{2}{*}{$\mathrm{LM}$ area, $\mathrm{cm}^{2}$} & $89.6^{\mathrm{a}}$ & $79.4^{\mathrm{c}}$ & $82.4^{\mathrm{b}}$ \\
\hline & $(0.13)$ & $(0.38)$ & $(0.89)$ \\
\hline \multirow[t]{2}{*}{$\mathrm{KPH}, \%$} & $2.2^{\mathrm{c}}$ & $2.3^{\mathrm{b}}$ & $2.5^{\mathrm{a}}$ \\
\hline & $(0.009)$ & $(0.03)$ & $(0.06)$ \\
\hline \multirow[t]{2}{*}{ Marbling score ${ }^{3}$} & $440^{\mathrm{b}}$ & $451^{\mathrm{a}}$ & $424^{\mathrm{c}}$ \\
\hline & $(1.1)$ & $(3.3)$ & $(7.7)$ \\
\hline \multirow[t]{2}{*}{ Lean maturity $^{4}$} & $155^{\mathrm{a}}$ & $154^{\mathrm{a}}$ & $152^{\mathrm{a}}$ \\
\hline & $(0.3)$ & $(1.0)$ & $(2.3)$ \\
\hline \multirow[t]{2}{*}{ Skeletal maturity ${ }^{4}$} & $163^{\mathrm{a}}$ & $157^{\mathrm{b}}$ & $154^{\mathrm{b}}$ \\
\hline & $(0.4)$ & $(1.2)$ & $(2.7)$ \\
\hline \multirow[t]{2}{*}{ Overall maturity $^{4}$} & $160^{\mathrm{a}}$ & $156^{\mathrm{b}}$ & $154^{\mathrm{b}}$ \\
\hline & $(0.3)$ & $(1.0)$ & $(2.3)$ \\
\hline
\end{tabular}

\footnotetext{
${ }^{\mathrm{a}-\mathrm{d}}$ Means within a row lacking a common superscript letter differ $(P<0.05)$.

${ }^{1} \mathrm{SEM}$ is the SE of the least squares means.

${ }^{2} 100=$ Canner $^{00}, 400=$ Commercial $^{00}, 600=$ Select $^{00}$, and $800=$ Prime $^{00}$.

${ }^{3} 100=$ Practically devoid $^{00}, 300=$ Slight $^{00}, 500=$ Modest $^{00}$, and $700=$ Slightly Abundant ${ }^{00}$.

${ }^{4} 100=\mathrm{A}^{00}$ and $500=\mathrm{E}^{00}$.
} 
APPENDIX B

\begin{tabular}{|c|c|c|c|c|c|c|c|c|c|}
\hline Car. ID/Sequence \# & L. MAT. & A & B & $\mathrm{C}$ & $\mathrm{D}$ & $\mathrm{E}$ & & & \\
\hline Car. Wt. (lbs.)_ & S. MAT. & A & B & $\mathrm{C}$ & $\mathrm{D}$ & $\mathrm{E}$ & & & \\
\hline $\operatorname{REA}\left(\mathrm{in}^{2}\right)$ & PYG & 1 & 2 & 3 & 4 & 5 & & & \\
\hline $\begin{array}{lllll}\text { Sex: } & \text { S } & \text { H } & \text { B } & \text { C }\end{array}$ & $\%$ КРН & 0 & 1 & 2 & 3 & 4 & 5 & & \\
\hline Native & MARB & PD & TR & SL & SM & MT & MD & SA & MA \\
\hline Brahman & DARK C. & $1 / 3$ & $1 / 2$ & $2 / 3$ & FULL & B. Spl. & Call. & Yellow Fat & \\
\hline Dairy & PROGRAM & $\mathrm{CAB}$ & Top Ch. & NHTC & $\mathrm{A} 40$ & $\mathrm{G}_{-}$ & \multicolumn{2}{|c|}{ In-House_ } & \\
\hline USA CAN MEX & & $\begin{array}{l}\text { Angus } \\
\text { Stamp }\end{array}$ & Organic & Natural & ASV & 30 Month & \multicolumn{2}{|c|}{ Other_ } & \\
\hline
\end{tabular}

Figure 1. Example of data sheet used during data collection. 
Relationship Between Marbling, Maturity, and Carcass Quality Grade*

\begin{tabular}{|c|c|c|c|c|c|c|}
\hline \multirow[b]{2}{*}{$\begin{array}{l}\text { Degrees of } \\
\text { Marbling }\end{array}$} & \multicolumn{5}{|c|}{ Maturity"• } & \multirow[b]{2}{*}{$\begin{array}{l}\text { Degrees of } \\
\text { Marbling }\end{array}$} \\
\hline & $A^{* * * *}$ & B & C & D & $E$ & \\
\hline $\begin{array}{l}\text { Slightly } \\
\text { Abundant }\end{array}$ & Prime & & & & & $\begin{array}{l}\text { Slightly } \\
\text { Abundant }\end{array}$ \\
\hline Moderate & & & Commercial & & & Moderate \\
\hline Modest & Choice & & & & & Modest \\
\hline Small & & & & & & Small \\
\hline Slight & Select & & & Utility & & Slight \\
\hline Traces & & & & & atter & Traces \\
\hline $\begin{array}{l}\text { Practically } \\
\text { Devoid }\end{array}$ & Standard & & & & & $\begin{array}{l}\text { Practically } \\
\text { Devoid }\end{array}$ \\
\hline
\end{tabular}

- Assumes that firmness of lean is comparably developed with the degree of marbling and that the carcass is not a "dark

* Maturity increases from left to right (A through E).

-.. The A maturity portion of the Figure is the only portion applicable to bullock carcasses.

Figure 2. Relationship between marbling, maturity, and carcass quality grade chart (USDA, 1997). 


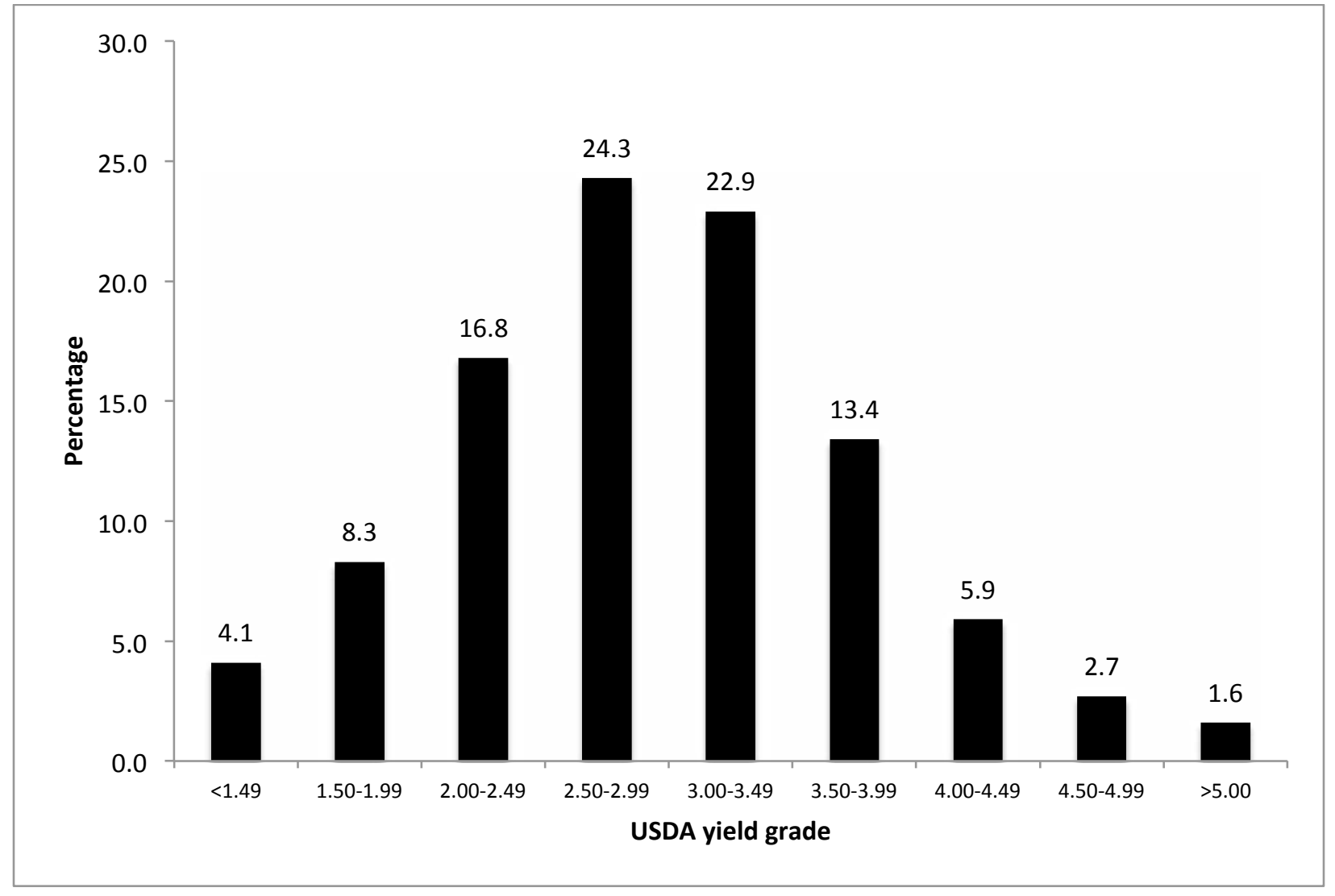

Figure 3. Frequency distribution of carcass by one-half yield grade increments. 


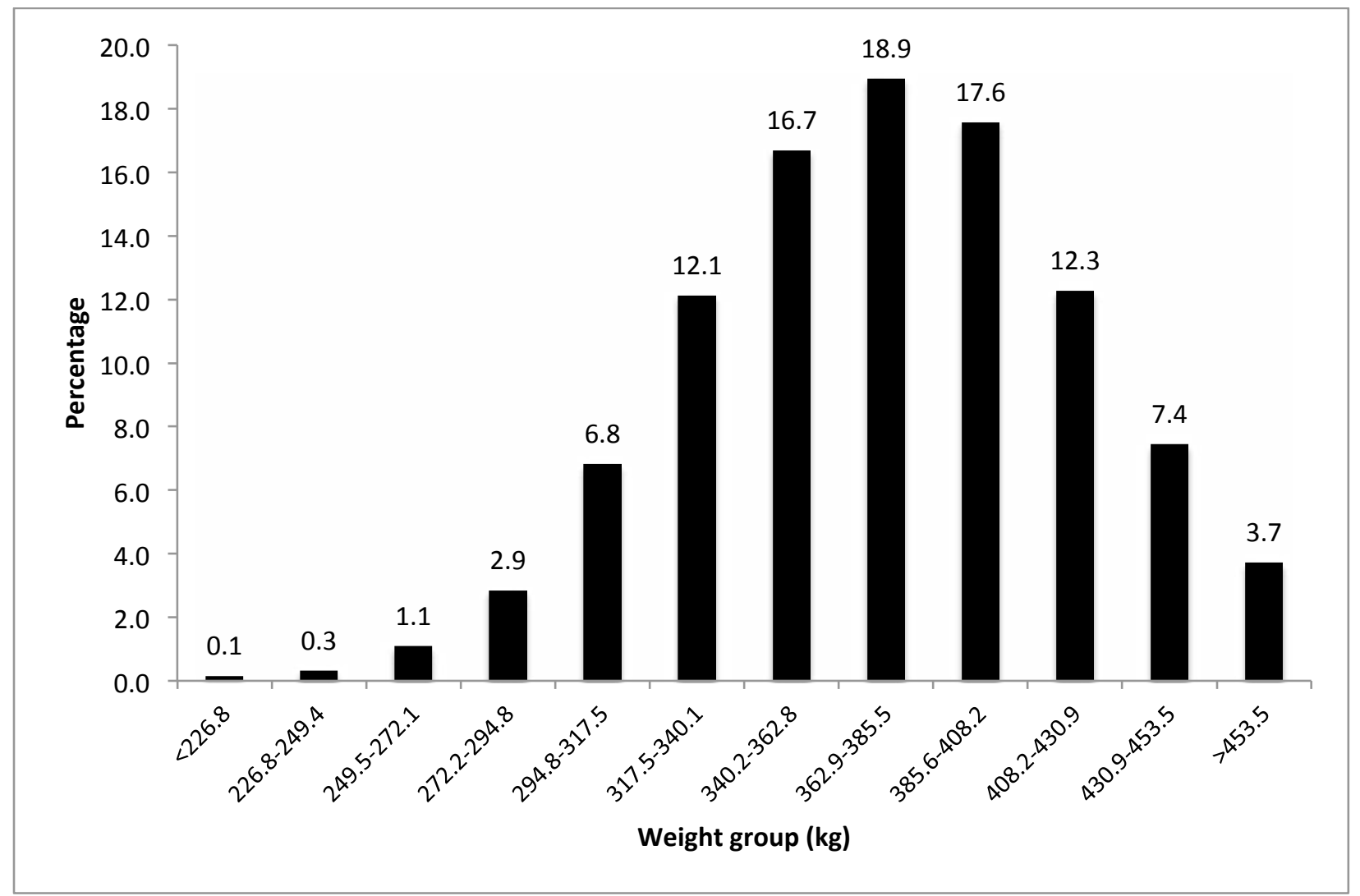

Figure 4. Frequency distribution of carcasses by weight groups. 


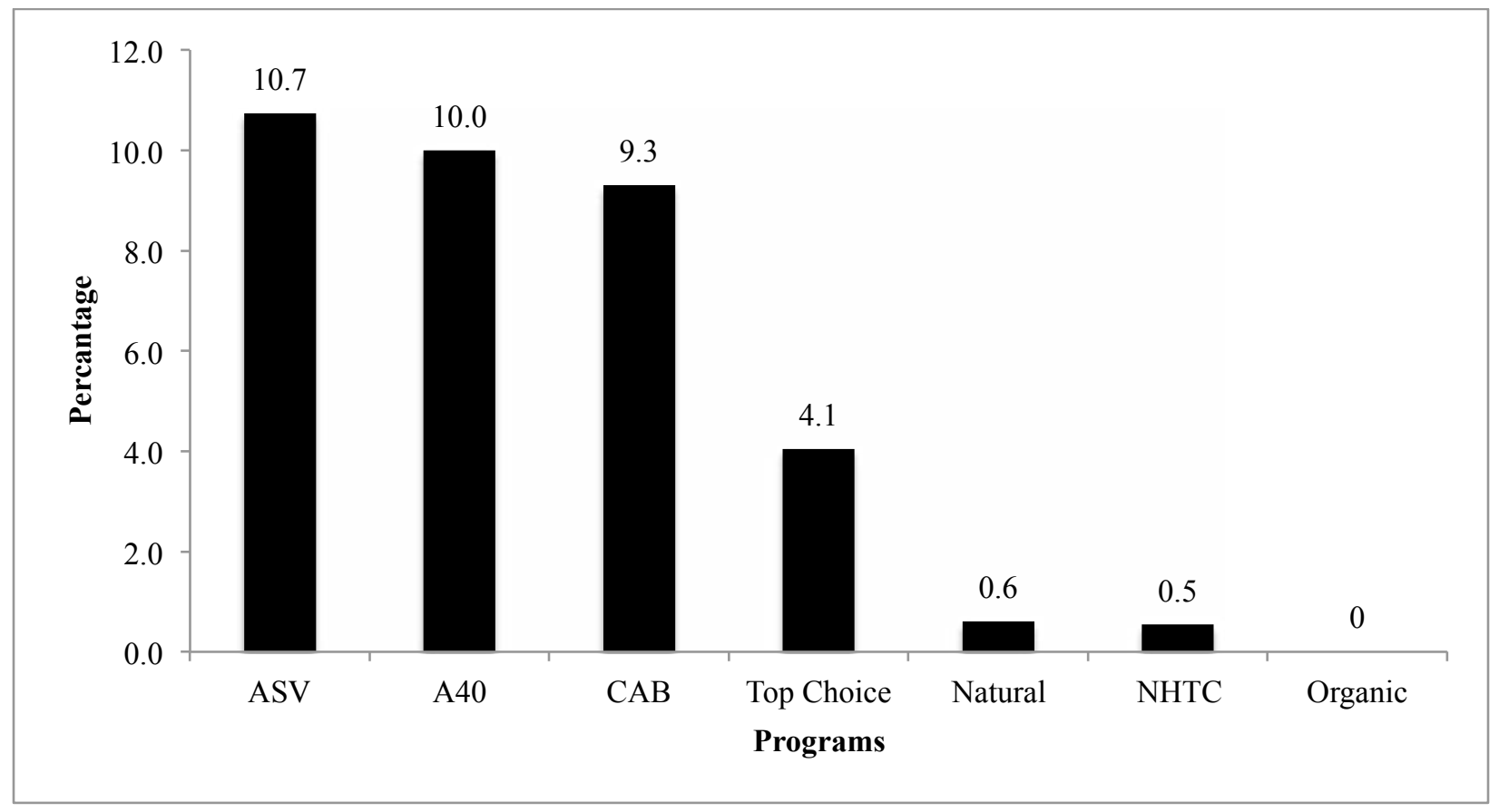

Figure 5. Frequency distribution of different certified and marketing programs. ASV is age and source verified; A40 is for carcasses that meet the carcass maturity requirements for exporting to Japan; CAB is Certified Angus Beef; Top Choice is all other top Choice programs other than CAB; Natural is for carcasses qualifying for natural programs; NHTC is Non-Hormone Treated Cattle; and Organic is for carcasses qualify for organic programs. 